\title{
บUsisersily
}

\section{Caught in the crossfire: Dimensions of vulnerability and foreign multinationals exit from war-afflicted countries}

Dai, L., Eden, L., \& Beamish, P. W. (2017). Caught in the crossfire: Dimensions of vulnerability and foreign multinationals exit from war-afflicted countries. Strategic Management Journal, 38(7), 1478-1498. https://doi.org/10.1002/smj.2599

Link to publication record in Ulster University Research Portal

\section{Published in:}

Strategic Management Journal

Publication Status:

Published (in print/issue): 31/07/2017

DOI:

10.1002/smj.2599

\section{Document Version}

Author Accepted version

\section{General rights}

Copyright for the publications made accessible via Ulster University's Research Portal is retained by the author(s) and / or other copyright owners and it is a condition of accessing these publications that users recognise and abide by the legal requirements associated with these rights.

\section{Take down policy}

The Research Portal is Ulster University's institutional repository that provides access to Ulster's research outputs. Every effort has been made to ensure that content in the Research Portal does not infringe any person's rights, or applicable UK laws. If you discover content in the Research Portal that you believe breaches copyright or violates any law, please contact pure-support@ulster.ac.uk. 


\title{
CAUGHT IN THE CROSSFIRE: DIMENSIONS OF VULNERABILITY
}

\section{AND FOREIGN MULTINATIONALS' EXIT FROM WAR-AFFLICTED COUNTRIES}

\begin{abstract}

\section{Research Summary}

When war occurs in a country, some foreign MNEs stay on, while others flee. We argue that MNE responses to external threats depend on the firm's vulnerability, which we decompose into exposure (proximity to threat), at-risk resources (potential for loss), and resilience (capacity for coping). We test the independent and interactive effects of these dimensions using a georeferenced sample of 1,162 MNE subsidiaries in 20 war-afflicted countries over 1987-2006. We find that highly valuable resources can become liabilities when exposed to harm, and the best way to cope with external threats may be to exit. Our findings extend the resource based view and real options theory by demonstrating the bounded value of resources and options in the face of environmental contingencies.
\end{abstract}

\section{Managerial Summary}

A recent Economist Intelligence Unit survey of board-level MNE executives revealed that $30 \%$ of the respondents believed that their firms were exposed to collateral damage from war, with more than $90 \%$ expecting these risks to rise. Yet, $25 \%$ of the executives indicated that their firms had no continuity plan in place. Our study of MNEs operating in war-afflicted countries highlights the costs of not having a response strategy in place. We find that, in war zones, otherwise highly valuable locations and resources can become sources of vulnerability that prompt early firm withdrawal from a host country. Our work further highlights the value of real options thinking - where structural solutions such as building redundancy into a portfolio of options may exist in advance of problems - for navigating hostile environments. 


\section{INTRODUCTION}

The overseas operations of multinational enterprises (MNEs) are increasingly exposed to war. The number of violent wars worldwide, for example, rose from 176 in 2013 to 223 in 2015 (HIIK, 2013, 2015). MNE investments in least developed countries, many of which are afflicted by war, increased from $\$ 0.6$ billion in 1990 to $\$ 23.2$ billion in 2014 (UNCTAD, 2015). Despite the growing salience of war for MNEs, why and how they respond to outbreaks of war in host countries has received little attention in the field of management.

As high-consequence events, wars represent a significant political risk for MNEs, but are often treated as low probability and low potential-for-loss events (EIU, 2007). For example, during Libya's 2012 civil war, the firm Cinnabon chose to stay despite the bloodshed (BusinessWeek, 2012). In 2013, amid killings by militants in Algeria, foreign MNEs tightened security but none left the country (Krauss and Reed, 2013).

Since much of our understanding about firm strategies in war zones is gleaned from aggregate statistics or anecdotes, we know little about what explains MNEs' idiosyncratic responses. Our study helps to explain why some foreign MNEs stay on while others leave when war breaks out in a host country. We contend that exit rates depend on firm vulnerability, which we characterize in terms of three dimensions: exposure (the extent to which an external threat is experienced proximally), at-risk resources (the value of an MNE's global portfolio in the host country that would be extremely hard to replace if damaged) and resilience (capacity for coping with harm). We test our arguments for each dimension and their interactive effects using a georeferenced dataset for 1,162 MNE subsidiaries in 20 war-afflicted countries over 1987-2006.

Management scholars have traditionally viewed wars and other political violence through the lens of political risk (Kobrin, 1979). Our timely analysis revisits a fundamental question for 
theory on political risk: What makes some MNEs more vulnerable to political risk than others? By developing and testing an integrative framework for explaining firm vulnerability to external threats, we offer powerful evidence that within-country location is a critical aspect of strategy in extreme settings. In addition, we demonstrate how real options thinking - structuring redundancy into a portfolio of options and acquiring experience in similar contexts - can turn environmental uncertainty into a source of value as opposed to loss (Trigeorgis and Reuer, 2016). Our work also extends the resource based view by revealing important contingencies among the dimensions of vulnerability and by challenging the traditional appeal of exceptionally valuable resources.

\section{BACKGROUND, THEORY AND HYPOTHESES}

\section{War in the Host Country and Foreign MNE Vulnerability}

War is "a contested incompatibility where the use of armed force between two parties, of which at least one is the government of a state, results in at least 25 battle-related deaths in one calendar year" (Uppsala, 2015). We focus on war because, unlike terrorism or organized crime, its impact on firms is direct $(\mathrm{Li}, 2006)$. Also, while other types of political violence are by necessity unpredictable, war is typically subject to norms and conventions (Czinkota, Knight, Liesch, and Steen, 2010), making it more amenable to anticipation and subsequent strategizing.

The literature on MNE-war linkages is largely normative, with a focus on firm complicity (Guidolin and La Ferrara, 2007), ethical dilemmas (Jamali and Mirshak, 2010; Kolk and Lenfant, 2010), and political behavior (Getz and Oetzel, 2009). The emphasis on firm outcomes is more recent. Driffield, Jones, and Crotty (2013) look at why firms enter war-afflicted countries, noting firm size and ownership structure, along with industry and location, as important determinants. Oetzel and Getz (2012) examine MNE responses to war, showing that MNEs collaborate with local entities to manage violence, depending on the type of stakeholder pressure faced. Dai, Eden 
and Beamish (2013) apply a geographical lens to examine MNE exposure in war zones, finding survival to be contingent on where and with whom subsidiaries are located.

In this paper, we develop a theory of MNE responses to war that centers on the concept of vulnerability. In studies of natural disasters, vulnerability is used to gauge one's ability to endure events such as earthquakes and hurricanes (Gallopin, 2006). Broadly defined as the potential for loss, vulnerability reflects susceptibility to damage that makes it hard for one to preserve its structure and achieve its goals (Adger, 2000). Vulnerability typically depends on three factors: one's proximity to a threat, what it has at risk, and its ability to resist the threat's impact. For example, an entity's vulnerability to an earthquake is contingent on its distance from the epicenter, its likely losses due to the earthquake, and its emergency preparedness.

We apply the same logic to our analysis, arguing that the vulnerability of MNEs to war depends on their 1) exposure (proximity to the war), 2) at-risk resources (potential for loss from the war) and 3) resilience (ability to withstand stressors related to the war). Given that "the impact of most political events varies from firm to firm and from project to project" (Kobrin, 1982: 40), we expect the three vulnerability dimensions to exert unique impacts on firms.

Vulnerability in the context of firms has been characterized in terms of different survival prospects (Auster and Aldrich, 1984). We similarly characterize vulnerability in terms of exit rate, that is, a foreign MNE's failure to survive in the host country. From an MNE's perspective, war creates a dilemma of whether to extricate its investment from a precarious situation with costs and benefits attached to both exiting and staying. More importantly, the MNE must decide how long to persevere in the face of adversity and risk the destruction of hard-to-replace assets.

Failure to exit in a timely manner can entail costs that make it futile to sustain operations in the host country. War has the potential to drastically increase the cost of production, for 
instance, by rendering roads unusable such that supplies need to be flown in (Guidolin and La Ferrara, 2007). War is also known to disrupt a firm's sales and exports, destroy property, plant and equipment, and harm employees (Oetzel and Getz, 2012). Yet, even as staying in a war-torn country contributes to firm vulnerability, the cost of exit may be even higher. Since exits reduce local density, there may be returns to staying and opportunity costs from leaving, especially if an MNE - such as Shell in Nigeria (Frynas, 1998) - has a dominant position in the host country.

We argue that it is important to assess the vulnerability of MNEs in war zones in the context not only of challenges and downside risk (Miller and Reuer, 1996), but also opportunities and upside potential (Miller and Eden, 2006). Both over- and under-estimating a foreign MNE's costs of staying - as captured by its exposure, at-risk resources, and resilience - can lead foreign MNEs to make sub-optimal trade-offs in deciding if and when to exit. To further understand the dilemmas inherent in the exit-versus-stay calculus, we examine the independent and interactive effects of the three vulnerability dimensions on foreign MNEs in war-afflicted countries.

\section{Exposure}

External threats can be general and commonly experienced across entities, or specific to a particular entity. Exposure refers to the latter. Research on natural hazards depicts exposure in terms of geography. "Physical hazard exposure and susceptibility to hazards must be understood within a geographic framework, that is, the hazardousness of a specific place" (Cutter, Mitchell, and Scott, 2000: 731). In strategy research, location in the host country has long been recognized to affect the extent of political hazards experienced by a subsidiary (Hill, Hwang, and Kim, 1990; Kobrin, 1979; Murtha, 1991). Location has also been shown in mega events to determine which firms are subject to abrupt changes at a given time (Tilcsik and Marquis, 2013).

In the context of war, foreign MNEs tend to respond differently given their location in the 
host country relative to the war zone. For example, in 2015 Shell left Nigeria (Bloomberg, 2015), even as General Electric (GE) invested \$10 billion in new power plants (Caulderwood, 2014). While Shell was located in the politically violent Niger Delta, GE had locations in Abuja and Lagos, cities far removed from both the Niger Delta in the south and violence in the north.

Because it is difficult to anticipate where and against whom war will strike (Hiatt and Sine, 2013), exposure generates levels of uncertainty that undermine the value of postponing exit. Given exposure to war, the usual opportunity costs associated with exercising a withdrawal option are kept at a minimum since opportunities to exploit any upside potential in the host country become precarious. This may explain why foreign MNEs, after choosing to initially cope with the civil war in Syria in 2013, accelerated their exit when Damascus and Aleppo became engulfed in violence (Fielding-Smith and Kerr, 2013). Even foreign oil MNEs with military protection from the government in Algeria - that chose not to leave despite having their natural gas plants blown up - noted that: “There is a limit. If [we] don't think [we] can protect [our] people [we] will exit, as Chevron did in Sudan" (Krauss and Reed, 2013). We thus argue that:

Hypothesis 1: The greater a foreign MNE's exposure, the faster its rate of exit from a host country at war.

\section{At-Risk Resources}

Real options theory accords value to MNEs because they have options that span across national borders (Kogut and Kulatilaka, 1994). In the case of discretionary actions (exit) and sunk costs, such options allow firms to "avoid future outlays in the event of negative signals [...] and position themselves to seize upside opportunities systematically" (Tong and Reuer, 2007: 216). Instead of weighing opportunities against threats inside a war-afflicted country, an MNE can consider the range of possible opportunities and threats faced by its global network as a whole. The value of opportunities in a country is thus a negative function of their substitutability 
outside of the country, where decision to abandon operations depends on the presence of correlated options elsewhere in an MNE's option portfolio (Vassolo, Anand, and Folta, 2004).

We view the MNE as a portfolio of subsidiaries where each subsidiary is both a bundle of resources deployed by the parent firm to further its objectives (Dunning and Lundan, 2008) and a real option for future strategic choice (Bowman and Hurry, 1993; Myers, 1977). Other subsidiaries of the MNE that can replace the activities or functions of a subsidiary are real options in the portfolio that "allow preferential access to future opportunities" (Bowman and Hurry, 1993: 762) and that can also facilitate the MNE's withdrawal from a particular portfolio project (Trigeorgis, 1996). The former provides flexibility along the dimension of time, and the latter along the dimension of space. The fewer surrogates there are for a focal subsidiary, the more important the subsidiary is to the MNE's global portfolio as a bundle of resources.

From a resource bundling perspective, a subsidiary may be more at risk in the face of war if it accounts for a large or unique portion of an MNE's production, sales or employment and/or operates in the host country for specific locational reasons that benefit the MNE group (e.g., to obtain quality inputs or to sell to a critically important market). In these cases, the subsidiary has a portfolio position within the MNE group that is not easily replicated, and, in the event of the subsidiary's destruction, this facet of being hard to replace can pose non-trivial costs of staying. We thus conceptualize at-risk resources as the value of a focal subsidiary in terms of its "replacement options" within the MNE's portfolio of subsidiaries.

The resource based view, with its almost exclusive focus on the strengths of resources, overlooks the potential weaknesses - and the attendant costs - of valuable resources put in jeopardy. Logics rooted in "more and better" from the strategy literature may be problematic in contexts involving extreme danger where "less may be more". Even in the literature on system 
adaptation to natural hazards, resources are construed only in terms of their functional value i.e., for creating slack and mitigating damage (Linnenluecke, Griffiths, and Winn, 2012).

We argue, by contrast, for a broader conceptualization of resources that considers their at-risk value in extreme settings. Since valuable resources are by nature tacit, complex and firmspecific (Reed and DeFillippi, 1990), they are not predisposed to imitation by rivals (Barney, 1990) or even by a firm itself if lost. Such difficult-to-replace resources are context specific and only re-deployable in a very limited set of environments (Helfat and Lieberman, 2002).

Since valuable resources are required to overcome the costs of doing business abroad (Hymer, 1976), firms likely need to deploy resources of even greater value in high-risk countries. Precisely because these resources facilitate expansion abroad when doing "business as usual" (Zaheer and Mosakowski, 1997), they can increase firms' vulnerability if damaged. For example, during war-related kidnappings in Nigeria and Colombia, workers normally considered valuable assets became a source of vulnerability when their safety was threatened (Swanson, 2002).

The at-risk value of a focal subsidiary presents a foreign MNE with a dilemma between staying (and risk losing hard-to-replace resources) and exiting (and risk incurring opportunity costs from abandoning real options). For a hard-to-replace subsidiary, we argue that exit is less likely because the costs imposed on the MNE network of closure would be immediate and readily estimated. For instance, oil MNEs that hold country-specific licenses and physical property often find it too expensive to leave a country (Kolk and Lenfant, 2010). MNEs in nonextractive industries that shut host country operations also risk losing licenses, trademarks, and other intangible property to local firms. Due to localization, it could be very costly to exercise the option to abandon operations. The specificity to the MNE of resources with few replacement options thus imposes sunk costs on exit that may outweigh costs of staying (Williamson, 1985). 
On the other hand, if a subsidiary can be relatively easily substituted in an MNE portfolio, the MNE may choose to close it in times of upheaval in order to limit any costs accruable from staying (Belderbos and Zou, 2009; Benito, 2005). The ability to shift assets and activities within the MNE group reduces exit costs. Studies on economic crises (Chung, Lee, Beamish, and Isobe, 2010) and foreign exchange crises (Miller and Reuer, 1998; Rangan, 1998) show that MNEs with options elsewhere are likely to divest troubled subsidiaries. We expect a similar response to war: Rather than be left vulnerable, MNEs with replacement options (for less at-risk but nonetheless valuable resources) will consider the costs to staying to be higher than those of exit and choose to exit. Especially in crises, real options in the form of alternate investment bundles provide firms with the flexibility to pursue new opportunities (Sirmon, Ireland, and Hitt, 2007).

On balance, we expect foreign exit to be a high-cost maneuver that most MNEs would prefer to avoid or at least defer, especially under uncertainty. Exit costs are markedly higher if a subsidiary fulfills a critical role in the MNE group, and there are no or few alternatives to move operations elsewhere. While duplication in a portfolio of options reduces their realizable value in good times, it is the lack of such duplication that limits the value of options in a portfolio during bad times (Li and Chi, 2013). In such cases, subsidiaries without replacement options represent bundles of at-risk resources, where closure will likely disrupt MNE operations and result in large losses. Foreign MNEs with more at-risk resources in a host country will thus be slower to exit in response to war because the expected costs of exit exceed those of staying. We thus argue that:

Hypothesis 2: The greater a foreign MNE's at-risk resources, the lower its rate of exit from a host country at war.

\section{Resilience}

Resilience refers to the ability of entities to cope with external stressors and disturbances 
(Adger, 2000). Resilience to an external threat depends on (i) impact resistance (the ability to withstand a damaging impact as it occurs) and (ii) recovery speed (the ability to restore functions to a pre-disturbance or even improved state) (Linnenluecke and Griffiths, 2010). According to research on natural disasters, impact resistance is based on pre-existing capacities (Linnenluecke et al., 2012). This suggests that the ability of MNEs to confront and cope with threats in their environment depends on attitudes to risk developed from prior experience in war zones.

The accumulation of experience in unstable countries has been shown to enable MNE adaptation to upheaval in other countries (Delios and Henisz, 2003), and adaptation reduces firm vulnerability to threats (Fichman and Levinthal, 1991). In work on natural disasters, adaptation is viewed as a part of resilience that reflects learning in response to disturbances (Carpenter, Brock, and Hanson, 1999). Learning from prior foreign investment is similarly considered indispensable for MNEs to develop the instinct needed to recognize and better respond to volatility abroad ( $\mathrm{Li}$, 1995). Since MNEs that undergo extreme events have greater forecasting aptitude (Henisz, 2004), and MNEs that can skillfully interpret the context are better at adapting to risky situations (Paroutis and Pettigrew, 2007), MNEs with prior experience in politically risky countries should have greater adaptive capacity and faster recovery speed, that is, more ex ante resilience. Such MNEs should be better equipped to handle the outbreak of war and more likely to delay their exit.

MNEs without experience in war-afflicted countries, on the other hand, are less likely to be resilient; they lack tolerance for political instability because a steadfast attitude towards volatility is acquired only over time $(\mathrm{Li}, 1995)$. While war is an extraordinary event for inexperienced MNEs, it may be perceived by experienced MNEs as a mere fluctuation in the host country's level of political risk. Since "decisions depend on prior processes of human 
perception and evaluation" (Hitt and Tyler, 1991: 328), experience in war-torn countries is likely key in diminishing managers' perception of the threat from war. With more experience, resilient MNEs may have a higher threshold for tolerating the costs of staying in a war-afflicted country and refrain abandoning its operations early on, such that:

Hypothesis 3: The greater a foreign MNE's resilience, the slower its rate of exit from a host country at war.

\section{At-Risk Resources and Exposure}

When exposure to war is low, we expect that a foreign MNE's costs of exit will exceed its costs of staying, especially if its resources invested in the host country are hard to replace. The limited threat combined with high stakes should prompt the MNE to stay or at least postpone exit. As a case in point, in Mali's 2012 civil war, Randgold announced that it was "committed to Mali despite unrest". Since its most productive mining complex was 350 kilometers from the capital city, where the violence was located (Reuters, 2012), the MNE would have suffered little in staying but incurred high costs in abandoning its lucrative operations.

Yet, when exposure to war is high - posing significant and irreversible damage to a focal subsidiary and its employees - we argue that conditions change. While the economic cost of divesting an at-risk bundle of resources is high, the cost of staying for an exposed MNE is no longer confined to economic costs from firm closure, but also includes possible losses in terms of human lives. According to the resource based view, valuable resources have "isolating mechanisms" (Mahoney and Pandian, 1992) that stem from largely human-based processes: tacit knowledge, causal ambiguity, and unique historical conditions. The realization of value from these isolating mechanisms rests on their dedicated use in a certain time-space. In the event this time-space is disrupted, such resources - if exposed - suffer from a substantial reduction in value. 
As Le Breton-Miller and Miller (2015) point out, dependency on the context can make a resource uniquely valuable to a firm, but also leave a firm vulnerable to changes in context. Whereas the inimitability and non-substitutability of resources preclude their replication by other firms (Barney, 1991), this at-risk dimension of resources increases the difficulties of replacing resources by a firm itself if exposed to harm. The greater the at-risk value of resources invested in the host country, the greater the loss to the foreign MNE should a threshold of exposure to war be exceeded. While a foreign MNE with hard-to-replace resources in the host country will prefer to stay to capitalize on such resources, its exposure can dramatically raise the costs of staying, especially as managers tend to perceive threats more accurately than opportunities (Jackson and Dutton, 1988). As exit becomes the only option for containing catastrophic loss, we predict that:

Hypothesis 4: Greater at-risk resources positively moderates the relationship between a foreign MNE's exposure and its rate of exit from a host country at war.

\section{Resilience and Exposure}

When foreign MNEs are exposed to war, we expect more priority to be placed on limiting losses than on maintaining host country operations. Given low exposure, pressures to exit may be minimal. However, when exposure imposes exorbitant costs on staying in the host country, the value provided by resilience becomes more apparent. MNEs with experience in politically risky countries should, in contrast with the average loss-minimizing MNE, have a higher threshold for fleeing from war and therefore greater resilience in resisting the impact of war. In practical terms, for instance, such experience may enable MNEs to find medical support and emergency assistance with greater ease. Given the time constraints on decision making typical in crisis situations, moreover, knowledge and experience acquired from operating in other politically risky countries can help managers to grasp the context faster (Hodgkinson and Clarke, 2007).

Experience gained in specific settings furthermore reduces a firm's tendency to follow 
the decisions of other firms (Henisz and Delios, 2001; Lu, 2001). The ability to judge events in a war independent of the inevitable hype surrounding firm exits may induce even exposed MNEs to exercise their coping mechanisms and stay on. In alleviating the actual and perceived costs of being exposed to war, experience has the potential to reduce the urgency of exiting. Moreover, investments in risky locations typically occur due to strong locational draws (e.g., natural resources, large market), which motivate MNEs' entry despite their knowing the risks. Having invested in such a location, MNEs have even greater incentive to stay on in order to capitalize on opportunities, since the difficulties of setting up a subsidiary abroad increase the value of the wait-and-see option during uncertain times (Caves and Porter, 1976). We thus predict that:

Hypothesis 5: Greater resilience negatively moderates the relationship between a foreign MNE's exposure and its rate of exit from a host country at war.

\section{METHODS}

\section{Data and Sample}

We tested our hypotheses on a sample of 1,162 Japanese MNE subsidiaries operating in 20 war-afflicted countries between 1987 and 2006. Data on 724 parent firms from the Nikkei Economic Electronic Databank System were matched with subsidiary data from Toyo Keizai's Japanese Overseas Investments, by Country. The dataset covers all Japanese MNE investments abroad, and as such represents the most comprehensive source of data on MNEs in war-afflicted countries. War data were compiled from the Armed Conflict and Conflict Site datasets of the Uppsala Conflict Data Program, widely used by scholars and policy makers (Collier, Elliott, Hegre, Hoeffler, Reynal-Querol, and Sambanis, 2003). The composite risk ratings for countries in our dataset, according to International Political Risk Services, varied from 14.5 to 86.7 on a scale of 0 to 100 , suggesting that they are not particularly different from other countries.

To study MNE responses to war, we needed to pinpoint the locations of subsidiaries and 
wars using geographical coordinates. The data collection process involved locating information (e.g., phone number, industry, founding year, host country) for subsidiaries prior to determining and coding their addresses with geographic coordinates. Latitudes and longitudes were coded annually to account for the time-varying nature of subsidiary and war zone locations. For least developed countries with arbitrary records and obscure translations of intersections instead of streets - where most of the sampled wars occurred - this process meant spending up to an hour on determining and geocoding each address. We also examined old news articles to determine the addresses of subsidiaries that had been closed.

\section{Dependent Variable}

Exit likelihood. Exit is a variable, $E_{x t}$, that takes on a value of 1 if MNE $x$ exits in year $t$, and 0 otherwise. Observations start in 1987 and continue until an exit occurs, or is right-censored in 2006. Closures and sell-offs of all Japanese equity ownership are treated as exits (Delios and Makino, 2003). There were 146 exits in total, consisting of 135 closures and 13 sell-offs.

\section{Independent Variables}

Exposure. We measured exposure by first geocoding the address of each subsidiary with annually-varying latitude and longitude coordinates. War zones were geocoded using their center and radius as the smallest circles containing violence (Buhaug and Gates, 2002). We then applied the great-circle distance formula to the latitude and longitude of the subsidiaries and the center of the nearest war zone to calculate a distance, from which the war zone radius was subtracted. The final variable was coded as 1 when the calculated distance was negative and as 0 otherwise.

At-risk resources. The operationalization of this variable is based on the premise that subsidiaries are bundles of resources that can hold distinct structural positions and thus different real option values within the MNE's global portfolio (Tong and Reuer, 2007). Characterized in 
real options theory as a function of redundancies within an MNE (Belderbos and Zou, 2009), the value of a subsidiary is predicated on its network position and size in the MNE's portfolio. The less replaceable it is by other subsidiaries within the MNE group, the greater its at-risk value.

We therefore assessed at-risk resources by measuring the non-redundancy of a focal subsidiary (Chung et al., 2010), or its difficulty of being replaced by other subsidiaries in the MNE's network. To determine the number of possible replacements for a subsidiary, we counted the subsidiaries in its parent's portfolio in the same industry and at the same value chain stage (i.e., upstream or downstream). We then measured the at-risk value of a subsidiary by gauging its importance in terms of its size relative to replacements. To do so, we divided the employee count in the focal subsidiary by the employee count in its replacements. As shown in Equation 1.1:

$$
A R R_{i j t}=\frac{E_{i j k t}}{\sum_{z=1}^{Z} E_{i z t}}
$$

$A R R_{i j t}$ is the at-risk resources of MNE $i$ in host country $j, E_{i j k t}$ is the employee count in a focal subsidiary $k$, and $E_{i z t}$ is the employee count summed over replacement subsidiaries $z$ for the focal subsidiary in the MNE's global portfolio $(z=1, \ldots, Z)$, all measured in year $t$. A lower denominator translates into a higher value on this variable and greater at-risk resources.

Resilience. Resilience is the ability to cope with external stressors and disturbances (Adger, 2000) and has been characterized as "a latent, path-dependent capability that cannot be measured directly" (Ortiz and Bansal, 2015: 1). We created a proxy for resilience by performing a principal component factor analysis (PCA) with varimax rotation on the values of four variables, which yielded a principal component explaining $90.0 \%$ of the variance. The Cronbach's alpha of 0.95 suggests that the variables have good reliability. As Table 1 shows, the large loadings provide support for the convergent validity of the variables. The Kaiser-MeyerOlkin statistic of 0.81 , above the acceptable limit of 0.6 , verified the sampling adequacy of 
variables for the PCA (Kaiser, 1974). Bartlett's test of sphericity $(p=0.000)$ confirmed that the correlations between the variables were sufficiently large and therefore appropriate for PCA.

--- Insert Table 1 about here ---

The variables used to measure resilience are: i) the Political Risk Services (PRS) scores (reverse coded so that greater values reflect higher risk) of the countries in an MNE's portfolio, weighted by a ratio of the MNE's subsidiary count in a given country to its subsidiary count in the full portfolio, summed over all countries in the MNE's portfolio, as denoted in Equation 1.2:

$$
W P R S_{i t}=\sum_{j=1}^{n} P R S_{j t} \times \frac{S_{i j t}}{\sum_{j=1}^{n} S_{i j t}}
$$

where $W P R S_{i t}$ is the weighted PRS score of MNE $i, P R S_{j t}$ is the PRS score for country $j$ and $S_{i j t}$ is the subsidiary count of MNE $i$ in country $j$ given $n$ countries in MNE $i$ 's portfolio $(n=1, \ldots, N)$, all measured in year $t$; (ii) the number of war-afflicted countries in an MNE's portfolio; (iii) the number of subsidiaries an MNE has in war-afflicted countries; and (iv) logged MNE sales. The first three variables capture an MNE's experience dealing with and attitude towards political risk. The fourth variable is a proxy for MNE size, since resilience also depends on an MNE's capacity to absorb costs in coordinating subsidiaries in different countries (Kogut and Kulatilaka, 1994).

\section{Control Variables}

According to the foreign exit literature, exit may be a function of the age, performance, entry mode, and industry of a subsidiary; the sunk costs of its parent; and mimetic forces and macro conditions in the host country. We therefore included controls for these alternative explanations of foreign exit.

At the subsidiary level, subsidiary age is used to account for host country experience (Chung and Beamish, 2005). Since profitable subsidiaries are less likely to be closed than nonprofitable ones (Mata and Freitas, 2012), we controlled for subsidiary performance using self- 
reports by managers. This variable has three ordinal levels: 1 for gain (baseline), 2 for breakeven, and 3 for loss. Since greenfield investments are less likely to be divested (Mata and Portugal, 2000), we controlled for greenfield as 1 for greenfield entry and 0 otherwise. Industry dummies were included to account for whether the subsidiary is in a primary (baseline), manufacturing, wholesale, or service industry. Since divesting core businesses is harder (Li, 1995), we included a dummy variable parent industry to capture whether a subsidiary is in its parent's core industry.

At the parent level, we controlled for sunk costs as the parent's percentage of investment in a subsidiary. Given mimetic isomorphism in exit behavior, we controlled for peer exits, which is the number of Japanese subsidiaries in the same industry and host country as a focal subsidiary that exits in a year (Dai et al., 2013).

At the country level, to account for the role of policy in shaping firm vulnerability beyond war's physical impact, we included a policy stability variable to proxy the extent to which political actors are constrained in policy decisions (Henisz, 2000), with values ranging from 0 (least stable) to 1 (most stable). Finally, we controlled for market attractiveness of the host country using the ratio of FDI flows to GDP (Delios and Henisz, 2003).

\section{Statistical Analysis}

Our empirical work is concerned with the relative rates of exit of foreign MNEs from war-torn host countries. We therefore employ non-parametric Cox proportional hazard models to test the probability that exit occurs within a particular time interval, given firm survival up to that point (Cox, 1972). In order to accurately gauge rates of exit in response to war, we format multiple "onsets of risk" in our hazard models to capture true periods of war. For example, five risk onsets were modeled for Iran to reflect war during the periods 1987-1988, 1990-1993, 1996-1997, 1999-2001, and 2005-2006. A focal subsidiary in Iran is assigned five IDs and its 
observations during peace removed by stratifying on the IDs. While modeling multiple failures is common in survival analysis, our method of dealing with multiple onsets of risk with a single failure (i.e., exit) is novel. We use robust standard errors clustered by country in order to relax the assumption that exits within the same host country are uncorrelated. Because foreign exits require time (McDermott, 2010), time-varying predictors and controls are lagged by one year.

The descriptive statistics and correlations are shown in Table 2. Subsidiaries had operated on average for 16.4 years in the host country, and $22 \%$ were located in war zones. In terms of performance, $68 \%$ of the subsidiaries had gains, $17 \%$ broke even, and $15 \%$ incurred losses. The most represented countries were the Philippines (29\%), Thailand (29\%) and Indonesia (23\%), together accounting for $66 \%$ of the exits. The most common industries were automobile (15\%), electronics (12\%) and chemicals (11\%), together accounting for $29 \%$ of the exits. We assessed multi-collinearity; the individual and mean variance inflation factors were below 2 for all models, and below the recommended threshold of 10 (Cohen, Cohen, West, and Aiken, 2003).

--- Insert Table 2 about here ---

\section{RESULTS}

Results of the Cox proportional hazard analysis obtained using standardized coefficients are shown in Table 3. A positive coefficient implies both a higher likelihood of exit and an earlier rather than a later exit (Kleinbaum and Klein, 2005). Model 1 presents the controls only. Models 2 to 5 consider the impact of exposure, at-risk resources, and resilience on exit. Models 6 and 7 test the moderation of exposure by at-risk resources and resilience, respectively.

--- Insert Table 3 about here ---

We interpret our results using Model 8, the full model. We use hazard ratios, as shown in Table 4, to discuss the practical significance of our findings. The hazard ratio, which gives the 
effect size, is computed as $100\left(e^{\beta}-1\right)$, or percentage change in the hazard with each one unit change in the predictor. A higher hazard ratio reflects a higher likelihood as well as a faster rate of exit (Tan and Vertinsky, 1996). Exposure is, as predicted in H1, positively associated with exit $(\beta=0.50, p=0.000)$. The hazard ratio of 1.65 for exposure suggests that exit for exposed MNEs is $65 \%$ faster than for unexposed MNEs. H2 predicting that at-risk resources is negatively related to exit is also supported $(\beta=0.24, p=0.000)$. For MNEs with at-risk resources, the exit rate is reduced by $21 \%$. Contrary to our theory, resilience has a positive impact on exit $(\beta=0.59$, $p=0.000) . \mathrm{H} 3$ is thus not supported; more resilient MNEs exit $81 \%$ faster than less resilient ones. --- Insert Table 4 about here ---

H4 predicting faster exit given an interaction between exposure and greater at-risk resources is supported $(\beta=0.59, p=0.000)$. In practical terms, having greater at-risk resources speeds up exit for exposed MNEs by $48 \%$. We plot the results in Figure 1, which shows (as predicted) that when exposure is low, the level of at-risk resources has little effect on exit rates. When exposure is high, the positive relationship between the exit rate and exposure increases rapidly for MNEs with greater at-risk resources in the country. The graph is consistent with our theory that exposing at-risk resources renders exit more urgent, even though the presence of such resources would normally deter exit. Estimating marginal effects, we see that the effect of exposure differs by the level of at-risk resources. Exposure increases exit rates by $16 \%$ for 10 units of at-risk resources, $46 \%$ for twice this level, and almost $95 \%$ for 40 units.

--- Insert Figure 1 about here ---

In support of $\mathrm{H} 5$, the exposure and resilience interaction term has a negative coefficient $(\beta=0.60, p=0.002)$. For exposed MNEs, resilience slows exit by $45 \%$. As shown in Figure 2 , less resilient MNEs exit at similar rates regardless of their exposure, although exit is slightly 
faster for exposed MNEs. The graph also confirms our predictions that even unexposed MNEs with less urgency to exit will exhibit faster exit if they have less resilience, as MNEs are more likely to overreact to unfamiliar situations. Given high resilience, however, exit is slower for exposed MNEs. Below 2 units of resilience, exposure has a minimal effect on exit rates ( $0 \%$ to 3\%). Yet, past this threshold level the discrepancy in exit rates becomes non-trivial, as exposed MNEs are able to delay exit and unexposed MNEs can exit faster. At higher levels of resilience, exit rates for exposed MNEs are reduced by nearly 3\% at 2 units of resilience and 13\% at 4 units. --- Insert Figure 2 about here ---

\section{Robustness Checks}

In addition to using regressors measured at time $t$ - 1 in our models, we use instrumental variables (IV) methods to address the possible endogeneity of our independent variables due to unobserved heterogeneity. As shown in Table 5, Models 1 to 3 present the results from the IV first-stage regressions. Models 4 to 6 report the results from the second-stage regressions with all three predictors treated as endogenous and replaced by their fitted values from the first-stage regressions. Models 7 to 9 contain the results from the second-stage regressions in which the focal predictors and interactions are instrumented for. The results were robust to the introduction of all regressors treated with exogenous instruments. We elaborate on our approach below.

--- Insert Table 5 about here ---

We begin by estimating the relationship between MNE exit rate and exposure using treatment effects models to account for potentially non-random location in war zones. In these models, a first-stage regression is estimated where each MNE's propensity to locate in war zones at $t-1$ is the dependent variable and the instrumental variable is a measure of war zone coverage in the host country at $t$-2. In our search for an appropriate instrument, we looked for variables 
that were strongly correlated with the likelihood of being in a war zone, but not directly related to exit rates (Wooldridge, 2010). While the proportion of the host country's area affected by war at $t-2$ is a deterministic predictor of whether an MNE will have a war zone location at $t-1$ $\left(R^{2}=0.490, p=0.000\right)$, war zone coverage at $t-2$ does not directly affect the exit rates at $t$ of MNEs that are already in the host country at $t-1(p=0.299)$. Next, the estimated propensities are used in lieu of actual propensities in a treatment effects model. The null hypothesis in the Wald test of independent equations is that the first and second stage equations are independent $(\rho=0)$. The test reveals that there is no treatment effect of exposure on exit rates (Wald $\chi^{2}=0.06, p=0.807$ ).

We then employ exogeneity tests to examine whether the at-risk resources and resilience variables are endogenous. In the tests we include two instruments - at-risk resources and resilience - both measured at time $t$-2. Lagged versions of variables are commonly used in time series or panel data as instruments as they tend to directly affect the focal endogenous variables without rendering a direct impact on the outcome variable (Greene, 2000; Kennedy, 2003). The Wu-Hausman $F$-statistic is $1.638(p=0.201)$ for at-risk resources, suggesting the variable does not violate the assumption of no correlation between the independent variable and error term. In contrast, the Wu-Hausman $F$-statistic is $4.298(p=0.038)$ for resilience. The rejection of the null hypothesis that resilience is exogenous at the $p=0.05$ level suggests the endogeneity of resilience. Our use of survival analysis precluded the use of a formal IV approach to address the endogeneity of resilience. There are currently no statistical tools for addressing endogeneity in the context of proportional hazard models such as the Cox model (Atiyat, 2011) because IV methods are only able to provide unbiased estimates in certain settings, one of which is a linear model (Fisher, 2003). We therefore use generalized method of moments (GMM) IV estimation, which is sufficiently flexible to control for unobserved heterogeneity in panel data (Blundell and 
Bond, 1998). Also, in line with our instrument choice in the exogeneity tests, lagged endogenous variables are commonly employed in GMM IV estimation (Baum, Schaffer, and Stillman, 2003).

As with formal IV approaches, the consistency of the GMM estimator depends on the validity of the instruments. Models 2 and 3 of Table 5 show that their coefficient estimates are statistically significant in the first-stage regressions, suggesting that they are sufficiently strong. Durbin-Wu-Hausman tests provide additional evidence for their significance. Further confirming the relevance of our instruments, the first-stage $F$ statistic is $752.734(p=0.000)$ for at-risk resources and $638.378(p=0.000)$ for resilience - both above 10 (Staiger and Stock, 1997) indicating that the instruments are exogenous and strong (Shea partial $R^{2}=0.673$ and 0.394 ).

We also conducted tests of identification, as weak instruments can distort test statistics and cause misleading statistical inference (Hansen, Heaton, and Yaron, 1996). The Anderson canonical correlations and Kleibergen-Paap tests for under-identification yielded statistics with $p=0.000$ for both at-risk resources and resilience, suggesting that the models are identified, with instruments correlated sufficiently with the instrumented variables. The Cragg-Donald Wald $F$ test for weak identification yielded statistics greater than the 10\% maximal IV size Stock-Yogo critical values, which enabled us to reject the null hypothesis that our instruments are weak and to confirm the relevance of our instruments (Stock and Yogo, 2005). We present the results of all tests for the exogeneity and relevance of the instruments in the bottom panel of Table 5 .

In an additional effort to address endogeneity, we ran models by stratifying on a variable indicating whether MNEs had political ties, which may be correlated with unobserved resources or capabilities that also affect exit rates. Using a dummy variable to account for this in a pooled sample of MNEs with and without political ties is inappropriate since having political ties may be endogenous, that is, not random (c.f. Frynas, 1998). We applied a different baseline hazard to 
each stratum, where the unobserved frailty is assumed to be the same for MNEs in a stratum.

We also checked the robustness of our results to alternative operationalizations of at-risk resources. To begin with, we adjusted the measurement of "replacement subsidiaries" in the original formula for this variable to account for (i) other subsidiaries of the parent in the host country and (ii) other subsidiaries of the parent in the same industry and at the same stage of the value chain in the host country. Next, reverting to the original conception of replacement options in the global sense, we created an alternate proxy using the ratio of sales in the focal subsidiary to sales summed over its replacement subsidiaries in the parent's international portfolio.

We then ran our models with an added control for subsidiary sales, which is not included in the main analyses because of potential confounding with the employees variable. In addition, since firms with fewer than 100 employees may lack the capacity to strategically respond to war (Oetzel and Getz, 2012), we ran our models on a sample of subsidiaries that had more than 100 employees. Because wars can spill over into neighboring countries and exhibit region-level characteristics, we estimated robust standard errors clustered by region for all models.

Finally, we ran models controlling for the characteristics of the war. First, we checked if the source of the incompatibility mattered by adding a categorical variable denoting whether the war was fought over territory (baseline), government, or both. Second, we accounted for war type using a variable with three categories indicating whether the war was interstate, civil, or both. Third, we included a control for war intensity, which was measured using a dummy variable where 0 refers to 25 to 999 annual battle-related deaths and 1 refers to at least 1000 annual battle-related deaths. All results remained largely unchanged in sign and statistical significance, even improving in some instances relative to our reported results.

\section{DISCUSSION AND CONCLUSIONS}


We examine a form of political instability (war) and a type of strategic response (exit) that are increasingly salient worldwide. We provide insight into how foreign MNEs respond to external threats in the host country using the concept of vulnerability, which we theorize in terms of exposure, at-risk resources and resilience. With war as a natural laboratory, we demonstrate the role of sub-national location in determining the at-risk value of resources in extreme contexts. While MNEs can be vulnerable (i.e., due to having high stakes or lacking experience in war zones) without necessarily being exposed, we offer definitive evidence that exposed MNEs are vulnerable. We discuss the implications of our findings for theory and practice regarding strategic responses in high-risk contexts and conclude with agendas for future research.

While political risk scholars and managers have long asserted that firms experience war in idiosyncratic ways, research using country-level data has yielded at best equivocal evidence. Past empirical efforts in examining firm strategy in response to war and other external threats have been too far removed from the level of analysis of greatest concern to decision makers: on the ground in war zones. An important contribution of this work is thus the introduction of a means of quantifying sub-national exposure to war that challenges the space-neutrality of political risk within countries. In our study, for example, the conflict in southern Thailand shaped firm activity in Pattani province, but had no discernable impact in Bangkok. The Mindanao uprising in the Philippines and the violence in northeastern India were likewise characterized by geographically non-uniform distributions of warfare (Rustad, Buhaug, Falch, and Gates, 2011).

Our findings are corroborated by research showing that exposure to adversity enables firms to be better at coping with sudden environmental changes, more so than being endowed with favorable resources (Bradley, Aldrich, Shepherd, and Wiklund, 2011). Our analyses reveal that greater at-risk resources lead MNEs to stay on during war, which, given our findings for 
exposure, lends support to the real options thinking that there are key benefits to firms staying flexible in dynamic environments even when resource specificity is high (Trigeorgis and Reuer, 2016). The negative effect of at-risk resources on exit rates reflects real options logics pertaining to incentive and feasibility. First, the possible foreclosure of re-entry reduces the reversibility of an exit, which "significantly reduces for a long time the variety of choices that would be possible in the future" (Henry, 1974: 1006). Given such exorbitant opportunity costs associated with exit, MNEs with at-risk resources invested in the host country have less motivation to exit. Second, given the time and search costs required to assess the salvage value - the next best use - of dedicated at-risk resources in the host country, it may be difficult to expedite exit.

Even as at-risk resources make it costly to leave a country, the occurrence of war where these resources are located can exponentially increase the costs of not exiting. Our results for the moderation of exposure by at-risk resources show precisely this. We advance the notion of hardto-replace value to show that extreme contexts can render some resource attributes more salient for decision-making than others. Specifically, the at-risk dimension of valuable resources is compounded by their difficulty of being replaced. Our work on replacement options for these atrisk bundles of resources further demonstrates the importance of viewing resource investments in terms of their ability to generate choices (Bowman and Hurry, 1993). Since wars are often farremoved from political centers (Rustad et al., 2011), the exposure of at-risk resources make exit - not protection from the host country ruling regime - the sole means of reducing vulnerability.

Our findings suggest that superior resources, which normally form the basis for value creation, can actually increase losses in anomalous situations where these resources are subject to harm. By highlighting the impact of resources from becoming absent instead of being present, we contend that it is not resources per se but rather their replacement costs that become salient in 
strategic considerations when said resources are exposed to external threats. In contrast to the economic notion of costs associated with replacing a particular profit stream (Lindenberg and Ross, 1981), replacement costs in strategy may be attributable to the challenges in re-developing time-sensitive opportunities, project-specific relationships and human capital should these be lost. As such, replacement costs may be especially hard to quantify economically in war zones.

The inability to apply rational arguments in life-threatening situations may explain our findings for resilience. The main effect results suggest that resilience leads to faster exit. Since pessimistic risk estimates are made in the face of danger, and perception of danger is the most critical determinant of exit in emergencies (Perry, 1979), the exit imperative for decision makers may not be tempered by resilience. Nonetheless, the GMM IV models with endogeneity-treated resilience lend support to our theory that resilience helps to defer exit. For resilient but exposed MNEs, however, the GMM IV results show that the simplest way to cope may be to leave.

Our measure for resilience has some limitations that create opportunities for future research. First, we compare relative rates of exit, where the mean resilience in our sample is lower than the median. Low resilience, combined with high risk, makes exit rather than staying the more likely outcome. Second, we measured resilience in terms of war zone experience, but experienced MNEs may have more experience incurring costs associated with staying on in war zones. Indeed, MNEs with experience in politically risky countries should be better able to assess the costs and benefits of exiting versus staying in a war-torn country and choose to "cut their financial losses", lest there be human losses. Since iterative comparisons of business processes in different contexts increase the rate at which firms respond to turbulence (Ndofor, Sirmon, and He, 2011), experienced MNEs may exit even faster using foreign exit routines developed elsewhere. Because certain MNEs receive benefits when war erodes state control - e.g., Shell's 
dominant position in Nigeria's oil industry was predicated on the disarray in petroleum policy caused by war (Frynas and Mellahi, 2003) - resilience measured as political ties may have yielded different results. Third, our resilience measure included a proxy for parent size. With more slack to buffer operations from external shocks, larger MNEs may be able to delay their exit from a country even when the rationale for staying becomes obscure (Nachum and Song, 2011). However, larger MNEs may also be more vulnerable to policy shifts in turbulent times than smaller MNEs due to their propensity to control crucial sectors and resources in the host country (Kobrin, 1978).

By quantifying the location-delimited exposure of MNEs to external threats, we highlight the importance of geographical theorizing and modeling for management research. Given the consistently positive relationship we found between exposure and vulnerability, managers considering entry into a volatile country need to pay special attention to investment location within the country. Since the threat of physical harm can vary sporadically at the provincial or even neighborhood levels (Dai et al., 2013), local knowledge may be of singular importance.

Our findings contribute further to practice by showing the role of location in determining the extent to which resources represent an asset or a liability in extreme contexts. If resources face exposure to harm, managers should be especially selective in deploying valuable resources abroad. Also, notwithstanding perceptions that associate MNE exit with failure (McDermott, 2010), managers should have exit strategies in place prior to entering a country. Since processes of acquiring and divesting must be synchronized to create value (Sirmon and Hitt, 2009), MNE investments in risky locales may lose value unless a threshold for tolerating exposure to external threats is established ex-ante. Just as exit strategies should accompany foreign entries, re-entry options may be valuable for exiting firms if threats subside (Hadjikhani and Johanson, 1996). 
In treating hard-to-replace subsidiaries in the MNE portfolio as resources at risk, our work supports the notion that having a global network does not always or necessarily provide MNEs with real options that reduce downside risk (Miller and Reuer, 1998; Reuer and Leiblein, 2000; Tong and Reuer, 2007). That is, our study of real options in light of environmental contingencies suggests that any operational flexibility prescribed in the theory may be outweighed by the costs of maintaining exposed at-risk resources. Our results show that in war zones, otherwise valuable resources can come to represent a source of vulnerability that make it too costly to stay in a host country, unless MNEs can draw on redundancies located in safe countries in the global portfolio. While our study examines the exit rate of foreign MNEs in response to war, we expect that similar time-sensitive decisions, such as sequential exits and the likelihood or ability to exercise re-entry options, can also be analyzed using the real options lens. Further, the notion of replacement options we developed here can be used to examine how other outcomes, such as exit mode or firm performance, are affected by a subsidiary's non-redundant position in its parent's portfolio.

Received wisdom in real options dictates that functional duplication between any pair of options in a portfolio can lessen the option value of one if the other is exercised (Anand, Oriani, and Vassolo, 2007; Belderbos and Zou, 2009; Li and Chi, 2013; McGrath, 1997; Trigeorgis, 1996; Vassolo et al., 2004). In our study in the context of war, it is precisely such duplication and exercise of the replacement option that help to preserve the value of a focal option, i.e., the closed subsidiary. We thus offer novel evidence for the positive effect of redundancy in extreme contexts, in support of the ex-ante structuring of substitutability into option portfolios (Trigeorgis and Reuer, 2016). Since real options reflect preparedness, our results for at-risk resources and resilience point to the importance of option value over earnings value and that of early 
investment in shadow, or hidden, options (Bowman and Hurry, 1993). Indeed, with portfolios of options also conceived of as knowledge (Kogut and Zander, 1992), research on real options can yield insights for resilience in terms of experience and learning. This work thus highlights the value of real options thinking - where solutions can precede problems - for volatile contexts.

Our work provides an impetus to identify the conditions under which resilience may be more or less necessary for firms to survive - and more importantly, thrive - in extreme contexts. In countries characterized by instability, resilience is indispensable to MNEs with incentives to prolong their stay. We examined one such scenario, where the operations of a subsidiary would be hard to replicate elsewhere. Other sensitive contexts prompt further analyses on the boundary conditions of different types of resilience. As an example, if legitimacy concerns are greater than physical threats, MNE size may not provide as much protection as local stakeholder goodwill or home-host relations (Rangan and Sengul, 2009). In the same vein, firm experience in other war zones may not help as much as political risk insurance if the violence is targeted. Determining other moderators and mediators in the relationship between resilience and MNE strategy in turbulent contexts will be particularly valuable for the study of political risk.

By examining foreign MNE responses to war in the host country, this paper advances theory on important dimensions of firm vulnerability and delivers prescriptions for managing other external threats, such as natural disasters, disease outbreaks and mega events (Oh and Oetzel, 2011; Tilcsik and Marquis, 2013). We thus consider the scope - and imperative - of this inquiry to be far broader than the context of war. While we chose this empirical setting in order to isolate the mechanisms we posited to underlie firm vulnerability to war, the contingent nature of external threats has pervasive analogues in other settings. Contexts characterized by largescale disorder are increasingly widespread, where not only a firm's performance but also its mere 
survival is affected by its capacity to alleviate exposure and vulnerability. Because the extent to which this link exists may vary across industries and countries, we believe that how firms deal with environmental turbulence is a complex phenomenon that deserves more attention. 


\section{REFERENCES}

Adger WN. 2000. Social and ecological resilience: are they related? Progress in Human Geography 24(3): 347-364.

Anand J, Oriani R, Vassolo RS. 2007. Managing a portfolio of real options. In Real Options Theory (Advances in Strategic Management, Volume 24), Reuer JJ, Tong TW (eds). Emerald Group Publishing Limited: Boston, MA: 275-303.

Atiyat M. 2011. Instrumental variable modeling in a survival analysis framework. Doctoral dissertation, Pennsylvania State University.

Auster E, Aldrich H. 1984. Small business vulnerability, ethnic enclaves, and ethnic enterprise. In Ethnic Communities in Business, Ward R, Jenkins R (eds). Cambridge University Press: Cambridge, U.K.: 39-54.

Barney JB. 1990. The debate between traditional management theory and organizational economics: substantive differences or intergroup conflict? Academy of Management Review 15(3): 382-393.

Barney JB. 1991. Firm resources and sustained competitive advantage. Journal of Management 17(1): 99-120.

Baum CF, Schaffer ME, Stillman S. 2003. Instrumental variables and GMM: estimation and testing. Stata Journal 3(1): 1-31.

Belderbos R, Zou J. 2009. Real options and foreign affiliate divestments: a portfolio perspective. Journal of International Business Studies 40(4): 600-620.

Benito GRG. 2005. Divestment and international business strategy. Journal of Economic Geography 5(2): 235-251.

Bloomberg. 2015. Shell sells Nigerian oil lease for $\$ 1.7$ billion to local company. [Accessed 13 May 2016].

Blundell R, Bond S. 1998. Initial conditions and moment restrictions in dynamic panel data models. Journal of Econometrics 87(1): 115-143.

Bowman EH, Hurry D. 1993. Strategy through the option lens: an integrated view of resource investments and the incremental-choice process. Academy of Management Review 18(4): 760-782.

Bradley SW, Aldrich H, Shepherd DA, Wiklund J. 2011. Resources, environmental change, and survival: asymmetric paths of young independent and subsidiary organizations. Strategic Management Journal 32(5): 486-509.

Buhaug H, Gates S. 2002. The geography of civil war. Journal of Peace Research 39(4): 417-33.

Business Week. 2012. Cinnabon in Tripoli as Libya opens up to foreign business. [Accessed 13 May 2016].

Carpenter SR, Brock WA, Hanson PC. 1999. Ecological and social dynamics in simple models of ecosystem management. Conservation Ecology 3(2): 4.

Caulderwood K. 2014. Business as usual for multinationals like GE in Nigeria, despite Boko Haram violence. International Business Times 24 May.

Caves RE, Porter ME. 1976. Barriers to exit. In Essays in Industrial Organization in Honor of Joe Bain, Qualls DP, Masson RT (eds.). Ballinger: Cambridge, MA: 39-69.

Chung CC, Beamish PW. 2005. The impact of institutional reforms on the characteristics and survival of foreign subsidiaries in emerging economies. Journal of Management Studies 42(1): 35-62.

Chung CC, Lee SH, Beamish PW, Isobe T. 2010. Subsidiary expansion/contraction during times of economic crisis. Journal of International Business Studies 41(3): 500-516. 
Cohen J, Cohen P, West SG, Aiken LS. 2013. Applied Multiple Regression/Correlation Analysis for the Behavioral Sciences. Routledge: Abingdon, UK.

Collier P, Elliott V, Hegre H, Hoeffler A, Reynal-Querol M, Sambanis N. 2003. Breaking the Conflict Trap: Civil War and Development Policy. World Bank: Washington, D.C.

Cox DR. 1972. Regression models and life tables. Journal of the Royal Statistical Society Series 34: 187-220.

Cutter SL, Mitchell JT, Scott MS. 2000. Revealing the vulnerability of people and places: a case study of Georgetown County, South Carolina. Annals of the Association of American Geographers 90(4): 713-737.

Czinkota MR, Knight G, Liesch PW, Steen J. 2010. Terrorism and international business: a research agenda. Journal of International Business Studies 41(5): 826-843.

Dai L, Eden L, Beamish PW. 2013. Place, space, and geographical exposure: foreign subsidiary survival in conflict zones. Journal of International Business Studies 44(6): 554-578.

Delios A, Henisz WJ. 2003. Political hazards, experience, and sequential entry strategies: the international expansion of Japanese firms, 1980-1998. Strategic Management Journal 24(11): 1153-1164.

Delios A, Makino S. 2003. Timing of entry and the foreign subsidiary performance of Japanese firms. Journal of International Marketing 11(3): 83-105.

Driffield N, Jones C, Crotty J. 2013. International business research and risky investments: an analysis of FDI in conflict zones. International Business Review 22(1): 140-155.

Dunning JH, Lundan SM. 2008. Institutions and the OLI paradigm of the multinational enterprise. Asia Pacific Journal of Management 25(4): 573-593.

Economic Intelligence Unit (EIU). 2007. Country reports. London: Economic Intelligence Unit.

Fichman M, Levinthal DA. 1991. Honeymoons and the liability of adolescence: a new perspective on duration dependence in social and organizational relationships. Academy of Management Review 16(2): 442-468.

Fielding-Smith A, Kerr S. 2013. Business exodus aids Syria's neighbors. Financial Times. [Accessed 13 May 2016].

Frynas JG. 1998. Political instability and business: focus on Shell in Nigeria. Third World Quarterly 19(3): 457-478.

Frynas JG, Mellahi K. 2003. Political risks as firm-specific (dis)advantages: evidence on transnational oil firms in Nigeria. Thunderbird International Business Review 45: 541-565.

Gallopin GC. 2006. Linkages between vulnerability, resilience, and adaptive capacity. Global Environmental Change 16(3): 293-303.

Getz KA, Oetzel J. 2009. MNE strategic intervention in violent conflict: variations based on conflict characteristics. Journal of Business Ethics 89(4): 375-386.

Greene WH. 2000. Econometric Analysis. Prentice Hall: London, U.K.

Guidolin M, La Ferrara E. 2007. Diamonds are forever, wars are not. Is conflict bad for private firms? American Economic Review 97: 1978-1993.

Hadjikhani A, Johanson J. 1996. Facing foreign market turbulence: three Swedish multinationals in Iran. Journal of International Marketing 4(4): 53-74.

Hansen LP, Heaton J, Yaron A. 1996. Finite-sample properties of some alternative GMM estimators. Journal of Business \& Economic Statistics 14(3): 262-280.

Helfat CE, Lieberman MB. 2002. The birth of capabilities: market entry and the importance of pre-history. Industrial and Corporate Change 11(4): 725-760.

Heidelberg Institute for International Conflict Research (HIIK). 2013. Conflict Barometer 2013. 
Available at: http://hiik.de/de/konfliktbarometer/pdf/ConflictBarometer_2013.pdf.

Heidelberg Institute for International Conflict Research (HIIK). 2015. Conflict Barometer 2015. Available at: http://hiik.de/de/konfliktbarometer/pdf/ConflictBarometer_2015.pdf.

Henisz WJ. 2000. The institutional environment for multinational investment. Journal of Law, Economics, and Organization 16(2): 334-364.

Henisz WJ. 2004. Political institutions and policy volatility. Economics \& Politics 16(1): 1-27.

Henisz WJ, Delios A. 2001. Uncertainty, imitation, and plant location: Japanese multinational corporations, 1990-1996. Administrative Science Quarterly 46(3): 443-475.

Henry C. 1974. Investment decisions under uncertainty: the "irreversibility effect". The American Economic Review 64(5): 1006-1012.

Hiatt SR, Sine WD. 2014. Clear and present danger: planning and new venture survival amid political and civil violence. Strategic Management Journal 35(5): 773-785.

Hill CW, Hwang P, Kim WC. 1990. An eclectic theory of the choice of international entry mode. Strategic Management Journal 11(2): 117-128.

Hitt MA, Tyler BB. 1991. Strategic decision models: integrating different perspectives. Strategic Management Journal 12(5): 327-351.

Hodgkinson GP, Clarke I. 2007. Conceptual note: exploring the cognitive significance of organizational strategizing: a dual-process framework and research agenda. Human Relations 60(1): 243-255.

Hymer SH. 1976. The International Operations of National Firms. MIT: Cambridge, MA.

Jackson SE, Dutton JE. 1998. Discerning threats and opportunities. Administrative Science Quarterly 33(3): 370-387.

Jamali D, Mirshak R. 2010. Business-conflict linkages: visiting MNCs, CSR, and conflict. Journal of Business Ethics 93(3): 443-464.

Kaiser HF. 1974. An index of factorial simplicity. Psychometrika 39(1): 31-36.

Kennedy P. 2003. A Guide to Econometrics. MIT press: Boston, MA.

Kleinbaum DG, Klein M. 2005. Competing risks survival analysis. Survival Analysis: A SelfLearning Text, 391-461.

Kobrin SJ. 1978. When does political instability result in increased investment risk. Columbia Journal of World Business 13(3): 113-122.

Kobrin SJ. 1979. Political risk: review and reconsideration. Journal of International Business Studies 10(1): 67-80.

Kobrin SJ. 1982. Managing Political Risk Assessment. University of California Press: Berkeley, CA.

Kogut B, Kulatilaka N. 1994. Operating flexibility, global manufacturing, and the option value of a multinational network. Management Science 40(1): 123-139.

Kogut B, Zander U. 1992. Knowledge of the firm, combinative capabilities, and the replication of technology. Organization Science 3(3): 383-397.

Kolk A, Lenfant F. 2010. MNC reporting on CSR and conflict in Central Africa. Journal of Business Ethics 93(2): 241-255.

Krauss C, Reed S. 2013. Algerian attack puts focus on worker security. New York Times. [Accessed 13 May 2016].

Le Breton-Miller I, Miller D. 2014. The paradox of resource vulnerability: considerations for organizational curatorship. Strategic Management Journal 36(3): 397-415.

Li J. 1995. Foreign entry and survival: effects of strategic choices on performance in international markets. Strategic Management Journal 16(5): 333-351. 
Li Q. 2006. Political violence and foreign direct investment. Research in Global Strategic Management 12: 225-249.

Li Y, Chi T. 2013. Venture capitalists' decision to withdraw: the role of portfolio configuration from a real options lens. Strategic Management Journal 34(11): 1351-1366.

Lindenberg EB, Ross SA. 1981. Tobin's q ratio and industrial organization. Journal of Business 54: 1-32.

Linnenluecke MK, Griffiths A. 2010. Beyond adaptation: resilience for business in light of climate change and weather extremes. Business and Society 49(3): 477-511.

Linnenluecke MK, Griffiths A, Winn M. 2012. Extreme weather events and the critical importance of anticipatory adaptation and organizational resilience in responding to impacts. Business Strategy and the Environment 21(1): 17-32.

Lu JW. 2002. Intra-and inter-organizational imitative behavior: institutional influences on Japanese firms' entry mode choice. Journal of International Business Studies 33(1): 19-37.

Mahoney JT, Pandian JR. 1992. The resource-based view within the conversation of strategic management. Strategic Management Journal 13(5): 363-380.

Mata J, Freitas E. 2012. Foreignness and exit over the life cycle of firms. Journal of International Business Studies 43(7): 615-630.

Mata J, Portugal P. 2000. Closure and divestiture by foreign entrants: the impact of entry and post-entry strategies. Strategic Management Journal 21(5): 549-562.

McDermott MC. 2010. Foreign divestment. International Studies of Management and Organization 40(4): 37-53.

McGrath RG. 1997. A real options logic for initiating technology positioning investments. Academy of Management Review 22(4): 974-996.

Miller SR, Eden L. 2006. Local density and foreign subsidiary performance. Academy of Management Journal 49(2), 341-355.

Miller KD, Reuer JJ. 1998. Asymmetric corporate exposures to foreign exchange rate changes. Strategic Management Journal 19(12): 1183-1191.

Murtha T. 1991. Surviving industrial targeting: state credibility and public policy contingencies in multinational subcontracting. Journal of Law, Economics and Organization 7: 117-143.

Myers SC. 1977. Determinants of corporate borrowing. Journal of Financial Economics 5(2): 147-175.

Nachum L, Song S. 2011. The MNE as a portfolio: interdependencies in MNE growth trajectory. Journal of International Business Studies 42(3): 381-405.

Ndofor HA, Sirmon DG, He X. 2011. Firm resources, competitive actions and performance: investigating a mediated model with evidence from the in-vitro diagnostics industry. Strategic Management Journal 32(6): 640-657.

Oetzel J, Getz KA. 2012. Why and how might firms respond strategically to violent conflict? Journal of International Business Studies 43(2): 166-186.

Oh CH, Oetzel J. 2011. Multinationals' response to major disasters: how does subsidiary investment vary in response to the type of disaster and the quality of country governance? Strategic Management Journal 32(6): 658-681.

Ortiz-de-Mandojana N, Bansal P. 2015. The long-term benefits of organizational resilience through sustainable business practices. Strategic Management Journal, in press.

Paroutis S, Pettigrew A. 2007. Strategizing in the multi-business firm: strategy teams at multiple levels and over time. Human Relations 60(1): 99-135.

Perry RW. 1979. Evacuation decision-making in natural disasters. Mass Emergencies 4(1): 25- 
38.

Rangan S. 1998. Do multinationals operate flexibly? Theory and evidence. Journal of International Business Studies 29(2): 217-237.

Rangan S, Sengul M. 2009. The influence of macro structure on the foreign market performance of transnational firms: the value of IGO connections, export dependence, and immigration links. Administrative Science Quarterly 54(2): 229-267.

Reed R, DeFillippi RJ. 1990. Causal ambiguity, barriers to imitation, and sustainable competitive advantage. Academy of Management Review 15(1): 88-102.

Reuer JJ, Leiblein MJ. 2000. Downside risk implications of multinationality and international joint ventures. Academy of Management Journal 43(2): 203-214.

Reuters. 2012. Randgold says committed to Mali despite unrest. [Accessed 13 May 2016]

Rustad SCA, Buhaug H, Falch Å, Gates S. 2011. All conflict is local: modeling sub-national variation in civil conflict risk. Conflict Management and Peace Science 28(1): 15-40.

Sirmon DG, Hitt MA. 2009. Contingencies within dynamic managerial capabilities: interdependent effects of resource investment and deployment on firm performance. Strategic Management Journal 30(13): 1375-1394.

Sirmon DG, Hitt MA, Ireland RD. 2007. Managing firm resources in dynamic environments to create value: looking inside the black box. Academy of Management Review 32(1): 273-292.

Staiger D, Stock JH. Instrumental variables regression with weak instruments. Econometrica: Journal of the Econometric Society 65(3): 557-586.

Stock JH, Yogo M. 2005. Testing for weak instruments in linear IV regression. Identification and inference for econometric models: essays in honor of Thomas Rothenberg.

Swanson P. 2002. Fueling Conflict. Economies of Conflict: Private Sector Activity in Armed Conflict. Norway: Programme for International Co-Operation and Conflict Resolution, The Fafo Institute.

Tan B, Vertinsky I. 1996. Foreign direct investment by Japanese electronics firms in the U.S. and Canada: modeling timing of entry. Journal of International Business Studies 27(4): 655-681.

Tilcsik A, Marquis C. 2013. Punctuated generosity: how mega-events and natural disasters affect corporate philanthropy in U.S. communities. Administrative Science Quarterly 58(1): 111148.

Tong TW, Reuer JJ. 2007. Real options in multinational corporations: organizational challenges and risk implications. Journal of International Business Studies 38(2): 215-230.

Trigeorgis L. 1996. Real Options: Managerial Flexibility and Strategy in Resource Allocation. MIT Press: Boston, MA.

Trigeorgis L, Reuer JJ. 2016. Real options theory in strategic management. Strategic Management Journal, forthcoming.

UNCTAD. 2015. World Investment Report. Available at http://unctad.org/en/PublicationsLibrary/wir2015_en.pdf.

Uppsala, 2015. Conflict data program. Available at: http://ucdp.uu.se.

Vassolo RS, Anand J, Folta TB. 2004. Non-additivity in portfolios of exploration activities: a real options-based analysis of equity alliances in biotechnology. Strategic Management Journal 25(11): 1045-1061.

Williamson OE. 1985. The Economic Institutions of Capitalism. Simon and Schuster: New York. Wooldridge JM. 2010. Econometric Analysis of Cross Section and Panel Data. MIT Press: Boston.

Zaheer S, Mosakowski E. 1997. The dynamics of the liability of foreignness: a global study of 
survival in financial services. Strategic Management Journal 18(6): 439-446. 
Table 1: Principal Component Factor Analysis of Resilience Variables

\begin{tabular}{lccccc}
\hline Resilience Variable & Mean & S.D. & Loading & $\begin{array}{l}\text { Variance } \\
\text { Explained }\end{array}$ & $\begin{array}{l}\text { KMO } \\
\text { Statistic }\end{array}$ \\
\hline $\begin{array}{l}\text { Weighted PRS Scores Summed over } \\
\text { all Countries in MNE's Portfolio }\end{array}$ & 0.2720 & 0.1726 & 0.9292 & $90.00 \%$ & 0.8628 \\
$\begin{array}{l}\text { Number of War-Afflicted Countries } \\
\text { in MNE's Portfolio }\end{array}$ & 3.8756 & 4.0771 & 0.9543 & $4.85 \%$ & 0.7796 \\
$\begin{array}{l}\text { Number of War-Afflicted Country } \\
\text { Subsidiaries in MNE's Portfolio }\end{array}$ & 8.3220 & 12.1566 & 0.9822 & $4.29 \%$ & 0.7078 \\
MNE Sales (Logarithm) & 12.6307 & 2.3613 & 0.9280 & $0.86 \%$ & 0.9430 \\
\hline \hline
\end{tabular}


Table 2. Descriptive Statistics and Correlations ${ }^{\mathrm{a}}$

\begin{tabular}{|c|c|c|c|c|c|c|c|c|c|}
\hline Variable & Mean & S.D. & Min. & Max. & 1 & 2 & 3 & 4 & 5 \\
\hline 1. Exposure & 0.22 & 0.41 & 0.00 & 1.00 & & & & & \\
\hline 2. At-Risk Resources & 0.50 & 0.54 & 0.00 & 27.75 & 0.00 & & & & \\
\hline 3. Resilience & -0.32 & 0.56 & -0.67 & 4.02 & 0.01 & -0.06 & & & \\
\hline 4. Subsidiary Age & 16.37 & 9.00 & 1.00 & 73.00 & -0.13 & 0.03 & 0.13 & & \\
\hline 5. Sunk Costs & 53.13 & 29.89 & 0.00 & 100.00 & 0.15 & 0.01 & 0.04 & 0.01 & \\
\hline 6. Financial Breakeven & 0.17 & 0.37 & 0.00 & 1.00 & 0.04 & -0.02 & 0.00 & -0.06 & 0.02 \\
\hline 7. Financial Loss & 0.11 & 0.32 & 0.00 & 1.00 & 0.01 & 0.00 & 0.00 & -0.14 & 0.06 \\
\hline 8. Greenfield & 0.90 & 0.30 & 0.00 & 1.00 & 0.04 & 0.01 & -0.03 & -0.08 & 0.11 \\
\hline 9. Manufacturing & 0.63 & 0.48 & 0.00 & 1.00 & 0.00 & 0.09 & -0.16 & 0.00 & $\mathbf{0 . 0 8}$ \\
\hline 10. Wholesale & 0.07 & 0.26 & 0.00 & 1.00 & 0.01 & -0.08 & 0.14 & -0.02 & 0.01 \\
\hline 11. Services & 0.10 & 0.29 & 0.00 & 1.00 & 0.04 & -0.05 & 0.09 & -0.07 & -0.05 \\
\hline 12. Parent Industry & 0.65 & 0.48 & 0.00 & 1.00 & -0.02 & -0.01 & -0.36 & $\mathbf{0 . 0 7}$ & 0.00 \\
\hline 13. Peer Exits & 1.09 & 1.78 & 0.00 & 8.00 & 0.00 & -0.01 & -0.05 & -0.02 & $\mathbf{0 . 0 8}$ \\
\hline 14. Policy Stability & 0.37 & 0.14 & 0.04 & 0.60 & -0.08 & -0.01 & -0.08 & -0.13 & -0.09 \\
\hline \multirow[t]{2}{*}{ 15. Market Attractiveness } & 1.81 & 1.97 & -2.76 & 40.16 & 0.06 & -0.01 & 0.00 & -0.01 & 0.04 \\
\hline & 6 & 7 & 8 & 9 & 10 & 11 & 12 & 13 & 14 \\
\hline 7. Financial Loss & -0.23 & & & & & & & & \\
\hline 8. Greenfield & 0.05 & 0.01 & & & & & & & \\
\hline 9. Manufacturing & -0.04 & 0.01 & -0.05 & & & & & & \\
\hline 10. Wholesale & 0.08 & -0.02 & 0.06 & -0.45 & & & & & \\
\hline 11. Services & -0.04 & 0.01 & -0.01 & -0.45 & -0.20 & & & & \\
\hline 12. Parent Industry & -0.02 & -0.02 & -0.02 & 0.23 & -0.11 & -0.28 & & & \\
\hline 13. Peer Exits & 0.00 & 0.05 & 0.07 & 0.11 & -0.06 & -0.08 & $\mathbf{0 . 0 7}$ & & \\
\hline 14. Policy Stability & 0.02 & $\mathbf{0 . 0 3}$ & -0.02 & 0.07 & 0.00 & -0.08 & 0.00 & 0.05 & \\
\hline 15. Market Attractiveness & 0.00 & 0.02 & $\mathbf{0 . 0 3}$ & -0.06 & 0.00 & 0.13 & -0.02 & 0.16 & -0.05 \\
\hline
\end{tabular}

${ }^{\mathrm{a}} n=5,554$. Correlations in bold are significant at $p<.05$. 
Table 3. Coefficient Estimates of Cox Proportional Hazard Analyses Predicting Exit Rate

\begin{tabular}{|c|c|c|c|c|c|c|c|c|}
\hline & Model 1 & Model 2 & Model 3 & Model 4 & Model 5 & Model 6 & Model 7 & Model 8 \\
\hline & Controls & Exposure & $\begin{array}{l}\text { At-Risk } \\
\text { Resources }\end{array}$ & Resilience & $\begin{array}{l}\text { Main } \\
\text { Effects }\end{array}$ & $\begin{array}{l}\text { Exposure* } \\
\text { ARR }\end{array}$ & $\begin{array}{l}\text { Exposure* } \\
\text { Resilience }\end{array}$ & $\begin{array}{l}\text { Full } \\
\text { Model }\end{array}$ \\
\hline $\begin{array}{l}\text { Subsidiary } \\
\text { Age }\end{array}$ & $\begin{array}{l}0.166 \\
(0.05 / 0.00)\end{array}$ & $\begin{array}{l}0.280 \\
(0.07 / 0.00\end{array}$ & $\begin{array}{l}0.171 \\
(0.05 / 0.01)\end{array}$ & $\begin{array}{l}0.066 \\
(0.06 / 0.18)\end{array}$ & $\begin{array}{l}0.210 \\
(0.07 / 0.00)\end{array}$ & $\begin{array}{l}0.212 \\
(0.07 / 0.01)\end{array}$ & $\begin{array}{l}0.212 \\
(0.06 / 0.00)\end{array}$ & $\begin{array}{l}0.212 \\
(0.07 / 0.00)\end{array}$ \\
\hline Sunk Costs & $\begin{array}{l}-0.390 \\
(0.06 / 0.00)\end{array}$ & $\begin{array}{l}-0.374 \\
(0.07 / 0.00\end{array}$ & $\begin{array}{l}-0.395 \\
(0.06 / 0.00)\end{array}$ & $\begin{array}{l}-0.379 \\
(0.07 / 0.00)\end{array}$ & $\begin{array}{l}-0.387 \\
(0.08 / 0.00)\end{array}$ & $\begin{array}{l}-0.396 \\
(0.08 / 0.00)\end{array}$ & $\begin{array}{l}-0.397 \\
(0.08 / 0.00)\end{array}$ & $\begin{array}{l}-0.404 \\
(0.09 / 0.00)\end{array}$ \\
\hline $\begin{array}{l}\text { Financial } \\
\text { Breakeven }\end{array}$ & $\begin{array}{l}0.364 \\
(0.16 / 0.02)\end{array}$ & $\begin{array}{l}0.338 \\
(0.14 / 0.01\end{array}$ & $\begin{array}{l}0.363 \\
(0.15 / 0.02)\end{array}$ & $\begin{array}{l}0.228 \\
(0.15 / 0.25)\end{array}$ & $\begin{array}{l}0.155 \\
(0.18 / 0.41)\end{array}$ & $\begin{array}{l}0.146 \\
(0.18 / 0.23)\end{array}$ & $\begin{array}{l}0.121 \\
(0.20 / 0.36)\end{array}$ & $\begin{array}{l}0.110 \\
(0.20 / 0.59)\end{array}$ \\
\hline Financial Loss & $\begin{array}{l}0.448 \\
(0.12 / 0.00)\end{array}$ & $\begin{array}{l}0.281 \\
(0.18 / 0.12\end{array}$ & $\begin{array}{l}0.379 \\
(0.09 / 0.00)\end{array}$ & $\begin{array}{l}0.364 \\
(0.14 / 0.01)\end{array}$ & $\begin{array}{l}0.118 \\
(0.24 / 0.63)\end{array}$ & $\begin{array}{l}0.106 \\
(0.25 / 0.17)\end{array}$ & $\begin{array}{l}0.114 \\
(0.26 / 0.12)\end{array}$ & $\begin{array}{l}0.104 \\
(0.26 / 0.69)\end{array}$ \\
\hline Greenfield & $\begin{array}{l}-0.618 \\
(0.18 / 0.00)\end{array}$ & $\begin{array}{l}-0.505 \\
(0.21 / 0.04\end{array}$ & $\begin{array}{l}-0.599 \\
(0.18 / 0.00)\end{array}$ & $\begin{array}{l}-0.708 \\
(0.17 / 0.00)\end{array}$ & $\begin{array}{l}-0.554 \\
(0.16 / 0.00)\end{array}$ & $\begin{array}{l}-0.545 \\
(0.16 / 0.00)\end{array}$ & $\begin{array}{l}-0.539 \\
(0.16 / 0.00)\end{array}$ & $\begin{array}{l}-0.526 \\
(0.16 / 0.00)\end{array}$ \\
\hline Manufacturing & $\begin{array}{l}-0.173 \\
(0.14 / 0.20)\end{array}$ & $\begin{array}{l}0.056 \\
(0.13 / 0.73\end{array}$ & $\begin{array}{l}-0.181 \\
(0.14 / 0.45)\end{array}$ & $\begin{array}{l}-0.160 \\
(0.10 / 0.34)\end{array}$ & $\begin{array}{l}0.059 \\
(0.10 / 0.57)\end{array}$ & $\begin{array}{l}0.026 \\
(0.11 / 0.42)\end{array}$ & $\begin{array}{l}0.136 \\
(0.12 / 0.25)\end{array}$ & $\begin{array}{l}0.099 \\
(0.12 / 0.40)\end{array}$ \\
\hline Wholesale & $\begin{array}{l}0.320 \\
(0.27 / 0.25)\end{array}$ & $\begin{array}{l}0.877 \\
(0.39 / 0.02\end{array}$ & $\begin{array}{l}0.364 \\
(0.25 / 0.17)\end{array}$ & $\begin{array}{l}0.318 \\
(0.23 / 0.17)\end{array}$ & $\begin{array}{l}0.868 \\
(0.35 / 0.01)\end{array}$ & $\begin{array}{l}0.848 \\
(0.36 / 0.02)\end{array}$ & $\begin{array}{l}0.938 \\
(0.32 / 0.01)\end{array}$ & $\begin{array}{l}0.916 \\
(0.32 / 0.01)\end{array}$ \\
\hline Services & $\begin{array}{l}0.251 \\
(0.17 / 0.11)\end{array}$ & $\begin{array}{l}0.499 \\
(0.16 / 0.00\end{array}$ & $\begin{array}{l}0.257 \\
(0.17 / 0.13)\end{array}$ & $\begin{array}{l}0.142 \\
(0.20 / 0.16)\end{array}$ & $\begin{array}{l}0.470 \\
(0.19 / 0.01)\end{array}$ & $\begin{array}{l}0.480 \\
(0.19 / 0.03)\end{array}$ & $\begin{array}{l}0.489 \\
(0.19 / 0.01)\end{array}$ & $\begin{array}{l}0.506 \\
(0.19 / 0.01)\end{array}$ \\
\hline $\begin{array}{l}\text { Parent } \\
\text { Industry }\end{array}$ & $\begin{array}{l}-0.489 \\
(0.09 / 0.00)\end{array}$ & $\begin{array}{l}-0.439 \\
(0.13 / 0.00\end{array}$ & $\begin{array}{l}-0.468 \\
(0.10 / 0.00)\end{array}$ & $\begin{array}{l}-0.230 \\
(0.09 / 0.03)\end{array}$ & $\begin{array}{l}-0.277 \\
(0.12 / 0.02)\end{array}$ & $\begin{array}{l}-0.286 \\
(0.12 / 0.02)\end{array}$ & $\begin{array}{l}-0.281 \\
(0.11 / 0.02)\end{array}$ & $\begin{array}{l}-0.287 \\
(0.12 / 0.01)\end{array}$ \\
\hline Peer Exits & $\begin{array}{l}0.591 \\
(0.16 / 0.00)\end{array}$ & $\begin{array}{l}0.631 \\
(0.16 / 0.00\end{array}$ & $\begin{array}{l}0.600 \\
(0.16 / 0.00)\end{array}$ & $\begin{array}{l}0.572 \\
(0.16 / 0.00)\end{array}$ & $\begin{array}{l}0.623 \\
(0.15 / 0.00)\end{array}$ & $\begin{array}{l}0.621 \\
(0.15 / 0.00)\end{array}$ & $\begin{array}{l}0.633 \\
(0.16 / 0.00)\end{array}$ & $\begin{array}{l}0.632 \\
(0.15 / 0.00)\end{array}$ \\
\hline $\begin{array}{l}\text { Policy } \\
\text { Stability }\end{array}$ & $\begin{array}{l}-0.113 \\
(0.12 / 0.80)\end{array}$ & $\begin{array}{l}-0.090 \\
(0.09 / 0.21\end{array}$ & $\begin{array}{l}-0.112 \\
(0.11 / 0.16)\end{array}$ & $\begin{array}{l}-0.104 \\
(0.09 / 0.26)\end{array}$ & $\begin{array}{l}-0.091 \\
(0.08 / 0.25)\end{array}$ & $\begin{array}{l}-0.083 \\
(0.08 / 0.31)\end{array}$ & $\begin{array}{l}-0.116 \\
(0.08 / 0.24)\end{array}$ & $\begin{array}{l}-0.104 \\
(0.08 / 0.21)\end{array}$ \\
\hline $\begin{array}{l}\text { Market } \\
\text { Attractiveness }\end{array}$ & $\begin{array}{l}-0.976 \\
(0.21 / 0.00)\end{array}$ & $\begin{array}{l}-1.283 \\
(0.32 / 0.00\end{array}$ & $\begin{array}{l}-0.962 \\
(0.21 / 0.00)\end{array}$ & $\begin{array}{l}-0.757 \\
(0.19 / 0.00)\end{array}$ & $\begin{array}{l}-1.042 \\
(0.25 / 0.00)\end{array}$ & $\begin{array}{l}-1.057 \\
(0.26 / 0.00)\end{array}$ & $\begin{array}{l}-1.080 \\
(0.28 / 0.00)\end{array}$ & $\begin{array}{l}-1.094 \\
(0.27 / 0.00)\end{array}$ \\
\hline Exposure & & $\begin{array}{l}0.522 \\
(0.14 / 0.00\end{array}$ & & & $\begin{array}{l}0.579 \\
(0.18 / 0.00)\end{array}$ & $\begin{array}{l}0.569 \\
(0.18 / 0.01)\end{array}$ & $\begin{array}{l}0.495 \\
(0.15 / 0.01)\end{array}$ & $\begin{array}{l}0.501 \\
(0.15 / 0.00)\end{array}$ \\
\hline $\begin{array}{l}\text { At-Risk } \\
\text { Resources }\end{array}$ & & & $\begin{array}{l}0.023 \\
(0.05 / 0.19)\end{array}$ & & $\begin{array}{l}-0.046 \\
(0.08 / 0.56)\end{array}$ & $\begin{array}{l}-0.210 \\
(0.03 / 0.00)\end{array}$ & $\begin{array}{l}-0.077 \\
(0.08 / 0.15)\end{array}$ & $\begin{array}{l}-0.241 \\
(0.04 / 0.00)\end{array}$ \\
\hline Resilience & & & & $\begin{array}{l}0.444 \\
(0.04 / 0.00)\end{array}$ & $\begin{array}{l}0.453 \\
(0.08 / 0.00)\end{array}$ & $\begin{array}{l}0.478 \\
(0.08 / 0.00)\end{array}$ & $\begin{array}{l}0.572 \\
(0.10 / 0.00)\end{array}$ & $\begin{array}{l}0.593 \\
(0.11 / 0.00)\end{array}$ \\
\hline $\begin{array}{l}\text { Exposure X } \\
\text { ARR }\end{array}$ & & & & & & $\begin{array}{l}0.411 \\
(0.09 / 0.00)\end{array}$ & & $\begin{array}{l}0.394 \\
(0.10 / 0.00)\end{array}$ \\
\hline $\begin{array}{l}\text { Exposure X } \\
\text { Resilience } \\
\end{array}$ & & & & & & & $\begin{array}{l}-0.632 \\
(0.19 / 0.00) \\
\end{array}$ & $\begin{array}{l}-0.596 \\
(0.19 / 0.00) \\
\end{array}$ \\
\hline $\mathrm{N}$ & 8,130 & 6,080 & 8,033 & 7,423 & 5,551 & 5,551 & 5,551 & 5,551 \\
\hline pseudo $\mathrm{R}^{2}$ & 0.050 & 0.061 & 0.050 & 0.059 & 0.071 & 0.073 & 0.074 & 0.076 \\
\hline Wald $\chi^{2}$ & 1877.64 & 3784.02 & 2245.16 & 3104.73 & 3471.05 & 15746.75 & 29243.64 & 21307.07 \\
\hline AIC & 2801.007 & 1728.552 & 2739.096 & 2382.374 & 1455.167 & 1453.942 & 1452.049 & 1451.272 \\
\hline BIC & 2885.047 & 1815.818 & 2829.983 & 2472.235 & 1554.493 & 1559.889 & 1557.997 & 1563.841 \\
\hline
\end{tabular}

${ }^{a}$ Standardized coefficients with robust standard errors clustered by country and $\mathrm{P}>|\mathrm{z}|$ in brackets; two-tailed tests. 
Table 4. Hazard Ratios of Cox Proportional Hazard Analyses Predicting Exit Rate ${ }^{a}$

\begin{tabular}{|c|c|c|c|c|c|c|c|c|}
\hline & & 12 & Model 3 & Model 4 & Model 5 & Model 6 & Model 7 & Model 8 \\
\hline & Controls & Exposure & $\begin{array}{l}\text { At-Risk } \\
\text { Resources }\end{array}$ & Resilience & $\begin{array}{l}\text { Main } \\
\text { Effects }\end{array}$ & $\begin{array}{l}\text { Exposure } \\
* \text { ARR }\end{array}$ & $\begin{array}{l}\text { Exposure* } \\
\text { Resilience }\end{array}$ & $\begin{array}{l}\text { Full } \\
\text { Model }\end{array}$ \\
\hline $\begin{array}{l}\text { Subsidiary } \\
\text { Age }\end{array}$ & $\begin{array}{l}1.180 \\
(0.06 / 0.00)\end{array}$ & $\begin{array}{l}1.323 \\
(0.09 / 0.00)\end{array}$ & $\begin{array}{l}1.187 \\
(0.06 / 0.00)\end{array}$ & $\begin{array}{l}1.069 \\
(0.06 / 0.25)\end{array}$ & $\begin{array}{l}1.234 \\
(0.08 / 0.00)\end{array}$ & $\begin{array}{l}1.236 \\
(0.08 / 0.00)\end{array}$ & $\begin{array}{l}1.236 \\
(0.08 / 0.00)\end{array}$ & $\begin{array}{l}1.236 \\
(0.08 / 0.00)\end{array}$ \\
\hline $\begin{array}{l}\text { Sunk } \\
\text { Costs }\end{array}$ & $\begin{array}{l}0.677 \\
(0.04 / 0.00)\end{array}$ & $\begin{array}{l}0.688 \\
(0.05 / 0.00)\end{array}$ & $\begin{array}{l}0.673 \\
(0.04 / 0.00)\end{array}$ & $\begin{array}{l}0.685 \\
(0.05 / 0.00)\end{array}$ & $\begin{array}{l}0.679 \\
(0.05 / 0.00)\end{array}$ & $\begin{array}{l}0.673 \\
(0.05 / 0.00)\end{array}$ & $\begin{array}{l}0.673 \\
(0.05 / 0.00)\end{array}$ & $\begin{array}{l}0.668 \\
(0.05 / 0.00)\end{array}$ \\
\hline $\begin{array}{l}\text { Financial } \\
\text { Breakeven }\end{array}$ & $\begin{array}{l}.440 \\
0.23 / 0.02)\end{array}$ & $\begin{array}{l}1.402 \\
(0.20 / 0.02)\end{array}$ & $\begin{array}{l}1.437 \\
(0.22 / 0.02)\end{array}$ & $\begin{array}{l}1.256 \\
(0.19 / 0.12)\end{array}$ & $\begin{array}{l}1.168 \\
(0.22 / 0.41)\end{array}$ & $\begin{array}{l}1.158 \\
(0.21 / 0.43)\end{array}$ & $\begin{array}{l}1.129 \\
(0.23 / 0.55)\end{array}$ & $\begin{array}{l}1.116 \\
(0.23 / 0.59)\end{array}$ \\
\hline Financial Loss & $\begin{array}{l}1.565 \\
(0.18 / 0.00)\end{array}$ & $\begin{array}{l}1.324 \\
(0.24 / 0.11)\end{array}$ & $\begin{array}{l}1.461 \\
(0.14 / 0.00)\end{array}$ & $\begin{array}{l}1.439 \\
(0.20 / 0.01)\end{array}$ & $\begin{array}{l}1.125 \\
(0.27 / 0.63)\end{array}$ & $\begin{array}{l}1.112 \\
(0.28 / 0.67)\end{array}$ & $\begin{array}{l}1.121 \\
(0.29 / 0.66)\end{array}$ & $\begin{array}{l}1.109 \\
(0.29 / 0.69)\end{array}$ \\
\hline Greenfield & $\begin{array}{l}0.539 \\
(0.10 / 0.00)\end{array}$ & $\begin{array}{l}0.603 \\
(0.13 / 0.02)\end{array}$ & $\begin{array}{l}0.549 \\
(0.10 / 0.00)\end{array}$ & $\begin{array}{l}0.493 \\
(0.08 / 0.00)\end{array}$ & $\begin{array}{l}0.575 \\
(0.09 / 0.00)\end{array}$ & $\begin{array}{l}0.580 \\
(0.09 / 0.00)\end{array}$ & $\begin{array}{l}0.584 \\
(0.10 / 0.00)\end{array}$ & $\begin{array}{l}0.591 \\
(0.10 / 0.00)\end{array}$ \\
\hline Manufacturing & $\begin{array}{l}0.841 \\
(0.12 / 0.21)\end{array}$ & $\begin{array}{l}1.057 \\
(0.14 / 0.67)\end{array}$ & $\begin{array}{l}0.834 \\
(0.12 / 0.21)\end{array}$ & $\begin{array}{l}0.852 \\
(0.08 / 0.10)\end{array}$ & $\begin{array}{l}1.061 \\
(0.11 / 0.57)\end{array}$ & $\begin{array}{l}1.026 \\
(0.12 / 0.82)\end{array}$ & $\begin{array}{l}1.145 \\
(0.13 / 0.24)\end{array}$ & $\begin{array}{l}1.104 \\
(0.13 / 0.40)\end{array}$ \\
\hline Wholesale & $\begin{array}{l}1.377 \\
(0.37 / 0.24)\end{array}$ & $\begin{array}{l}2.403 \\
(0.92 / 0.02)\end{array}$ & $\begin{array}{l}1.438 \\
(0.36 / 0.15)\end{array}$ & $\begin{array}{l}1.374 \\
(0.31 / 0.16)\end{array}$ & $\begin{array}{l}2.382 \\
(0.84 / 0.01)\end{array}$ & $\begin{array}{l}2.336 \\
(0.84 / 0.02)\end{array}$ & $\begin{array}{l}2.555 \\
(0.82 / 0.00)\end{array}$ & $\begin{array}{l}2.500 \\
(0.81 / 0.01)\end{array}$ \\
\hline Services & $\begin{array}{l}1.285 \\
(0.22 / 0.15)\end{array}$ & $\begin{array}{l}1.648 \\
(0.26 / 0.00)\end{array}$ & $\begin{array}{l}1.293 \\
(0.21 / 0.12)\end{array}$ & $\begin{array}{l}1.153 \\
(0.23 / 0.47)\end{array}$ & $\begin{array}{l}1.601 \\
(0.30 / 0.01)\end{array}$ & $\begin{array}{l}1.617 \\
(0.31 / 0.01)\end{array}$ & $\begin{array}{l}1.630 \\
(0.31 / 0.01)\end{array}$ & $\begin{array}{l}1.658 \\
(0.32 / 0.01)\end{array}$ \\
\hline Parent Industry & $\begin{array}{l}0.613 \\
(0.06 / 0.00)\end{array}$ & $\begin{array}{l}0.645 \\
(0.08 / 0.00)\end{array}$ & $\begin{array}{l}0.626 \\
(0.06 / 0.00)\end{array}$ & $\begin{array}{l}0.794 \\
(0.07 / 0.01)\end{array}$ & $\begin{array}{l}0.758 \\
(0.09 / 0.02)\end{array}$ & $\begin{array}{l}0.751 \\
(0.09 / 0.02)\end{array}$ & $\begin{array}{l}0.755 \\
(0.09 / 0.01)\end{array}$ & $\begin{array}{l}0.750 \\
(0.09 / 0.01)\end{array}$ \\
\hline Peer Exits & $\begin{array}{l}1.806 \\
(0.30 / 0.00)\end{array}$ & $\begin{array}{l}1.880 \\
(0.29 / 0.00)\end{array}$ & $\begin{array}{l}1.822 \\
(0.29 / 0.00)\end{array}$ & $\begin{array}{l}1.772 \\
(0.29 / 0.00)\end{array}$ & $\begin{array}{l}1.864 \\
(0.28 / 0.00)\end{array}$ & $\begin{array}{l}1.861 \\
(0.28 / 0.00)\end{array}$ & $\begin{array}{l}1.883 \\
(0.29 / 0.00)\end{array}$ & $\begin{array}{l}1.881 \\
(0.29 / 0.00)\end{array}$ \\
\hline Policy Stability & $\begin{array}{l}0.893 \\
(0.10 / 0.33)\end{array}$ & $\begin{array}{l}0.914 \\
(0.08 / 0.29)\end{array}$ & $\begin{array}{l}0.894 \\
(0.10 / 0.32)\end{array}$ & $\begin{array}{l}0.901 \\
(0.09 / 0.27)\end{array}$ & $\begin{array}{l}0.913 \\
(0.07 / 0.25)\end{array}$ & $\begin{array}{l}0.920 \\
(0.07 / 0.30)\end{array}$ & $\begin{array}{l}0.890 \\
(0.07 / 0.17)\end{array}$ & $\begin{array}{l}0.901 \\
(0.07 / 0.21)\end{array}$ \\
\hline $\begin{array}{l}\text { Market } \\
\text { Attractiveness }\end{array}$ & $\begin{array}{l}0.377 \\
(0.08 / 0.00)\end{array}$ & $\begin{array}{l}0.277 \\
(0.09 / 0.00)\end{array}$ & $\begin{array}{l}0.382 \\
(0.08 / 0.00)\end{array}$ & $\begin{array}{l}0.469 \\
(0.09 / 0.00)\end{array}$ & $\begin{array}{l}0.353 \\
(0.09 / 0.00)\end{array}$ & $\begin{array}{l}0.348 \\
(0.09 / 0.00)\end{array}$ & $\begin{array}{l}0.340 \\
(0.09 / 0.00)\end{array}$ & $\begin{array}{l}0.335 \\
(0.09 / 0.00)\end{array}$ \\
\hline Exposure & & $\begin{array}{l}1.686 \\
(0.24 / 0.00)\end{array}$ & & & $\begin{array}{l}1.785 \\
(0.33 / 0.00)\end{array}$ & $\begin{array}{l}1.766 \\
(0.32 / 0.00)\end{array}$ & $\begin{array}{l}1.641 \\
(0.25 / 0.00)\end{array}$ & $\begin{array}{l}1.651 \\
(0.25 / 0.00)\end{array}$ \\
\hline $\begin{array}{l}\text { At-Risk } \\
\text { Resources }\end{array}$ & & & $\begin{array}{l}1.024 \\
(0.05 / 0.63)\end{array}$ & & $\begin{array}{l}0.955 \\
(0.08 / 0.56)\end{array}$ & $\begin{array}{l}0.810 \\
(0.02 / 0.00)\end{array}$ & $\begin{array}{l}0.926 \\
(0.08 / 0.35)\end{array}$ & $\begin{array}{l}0.786 \\
(0.03 / 0.00)\end{array}$ \\
\hline Resilience & & & & $\begin{array}{l}1.559 \\
(0.06 / 0.00)\end{array}$ & $\begin{array}{l}1.573 \\
(0.12 / 0.00)\end{array}$ & $\begin{array}{l}1.613 \\
(0.14 / 0.00)\end{array}$ & $\begin{array}{l}1.772 \\
(0.17 / 0.00)\end{array}$ & $\begin{array}{l}1.810 \\
(0.19 / 0.00)\end{array}$ \\
\hline $\begin{array}{l}\text { Exposure X } \\
\text { ARR }\end{array}$ & & & & & & $\begin{array}{l}1.508 \\
(0.14 / 0.00)\end{array}$ & & $\begin{array}{l}1.483 \\
(0.15 / 0.00)\end{array}$ \\
\hline $\begin{array}{l}\text { Exposure X } \\
\text { Resilience } \\
\end{array}$ & & & & & & & $\begin{array}{l}0.531 \\
(0.10 / 0.00) \\
\end{array}$ & $\begin{array}{l}0.551 \\
(0.10 / 0.00) \\
\end{array}$ \\
\hline $\begin{array}{l}\mathrm{N} \\
\text { pseudo } \mathrm{R}^{2}\end{array}$ & $\begin{array}{l}8130 \\
0.050\end{array}$ & $\begin{array}{l}6080 \\
0.061\end{array}$ & $\begin{array}{l}8033 \\
0.050\end{array}$ & $\begin{array}{l}7423 \\
0.059\end{array}$ & $\begin{array}{l}5551 \\
0.071\end{array}$ & $\begin{array}{l}5551 \\
0.073\end{array}$ & $\begin{array}{l}5551 \\
0.074\end{array}$ & $\begin{array}{l}5551 \\
0.076\end{array}$ \\
\hline Wald $\chi^{2}$ & 1877.64 & 3784.02 & 2245.16 & 3104.73 & 3471.05 & 15746.75 & 29243.64 & 21307.07 \\
\hline AIC & 2801.007 & 1728.552 & 2739.096 & 2382.374 & 1455.167 & 1453.942 & 1452.049 & 1451.272 \\
\hline BIC & 2885.047 & 1815.818 & 2829.983 & 2472.235 & 1554.493 & 1559.889 & 1557.997 & 1563.841 \\
\hline
\end{tabular}

${ }^{a}$ Hazard ratios are reported with robust standard errors clustered by country in brackets; two-tailed tests. 
Table 5. Treatment Effects and GMM Instrumental Variable Analyses Predicting Exit Rate ${ }^{\mathrm{a}}$

\begin{tabular}{|c|c|c|c|c|c|c|c|c|c|}
\hline & \multirow{2}{*}{\multicolumn{3}{|c|}{$\frac{\text { First Stage }}{\text { Dependent Variables }}$}} & \multicolumn{6}{|c|}{$\underline{\text { Second Stage }}$} \\
\hline & & & & & Main Eff & cts & & Full Mo & \\
\hline & (1) & $(2)$ & $(3)$ & $(4)$ & $(5)$ & (6) & $(7)$ & $(8)$ & $(9)$ \\
\hline & Exposure & $\begin{array}{l}\text { At-Risk } \\
\text { Resources }\end{array}$ & Resilience & $\begin{array}{l}\text { Treatment: } \\
\text { Exposure }\end{array}$ & $\begin{array}{l}\text { IV GMM: } \\
\text { ARR }\end{array}$ & $\begin{array}{l}\text { IV GMM: } \\
\text { Resilience }\end{array}$ & $\begin{array}{l}\text { Treatment: } \\
\text { Exposure }\end{array}$ & $\begin{array}{l}I V G M M: \\
A R R\end{array}$ & $\begin{array}{l}\text { IV GMM: } \\
\text { Resilience }\end{array}$ \\
\hline$\overline{\text { Subsidiary Age }}$ & $\begin{array}{l}-0.024 \\
(0.02 / 0.12)\end{array}$ & $\begin{array}{l}0.004 \\
(0.02 / 0.79)\end{array}$ & $\begin{array}{l}0.017 \\
(0.03 / 0.55)\end{array}$ & $\begin{array}{l}0.006 \\
(0.00 / 0.01)\end{array}$ & $\begin{array}{l}0.007 \\
(0.00 / 0.01)\end{array}$ & $\begin{array}{l}0.004 \\
(0.00 / 0.11)\end{array}$ & $\begin{array}{l}0.006 \\
(0.00 / 0.01)\end{array}$ & $\begin{array}{l}0.007 \\
(0.00 / 0.01)\end{array}$ & $\begin{array}{l}0.001 \\
(0.00 / 0.00)\end{array}$ \\
\hline Sunk Costs & $\begin{array}{l}0.012 \\
(0.01 / 0.06)\end{array}$ & $\begin{array}{l}0.018 \\
(0.01 / 0.02)\end{array}$ & $\begin{array}{l}-0.013 \\
(0.01 / 0.19)\end{array}$ & $\begin{array}{l}-0.014 \\
(0.00 / 0.00)\end{array}$ & $\begin{array}{l}-0.010 \\
(0.00 / 0.00)\end{array}$ & $\begin{array}{l}-0.010 \\
(0.00 / 0.00)\end{array}$ & $\begin{array}{l}-0.015 \\
(0.00 / 0.00)\end{array}$ & $\begin{array}{l}-0.009 \\
(0.00 / 0.00)\end{array}$ & $\begin{array}{l}-0.008 \\
(0.00 / 0.00)\end{array}$ \\
\hline Financial Breakeven & $\begin{array}{l}0.023 \\
(0.01 / 0.04)\end{array}$ & $\begin{array}{l}-0.013 \\
(0.02 / 0.48)\end{array}$ & $\begin{array}{l}0.063 \\
(0.08 / 0.46)\end{array}$ & $\begin{array}{l}0.004 \\
(0.00 / 0.04)\end{array}$ & $\begin{array}{l}0.007 \\
(0.00 / 0.10)\end{array}$ & $\begin{array}{l}0.001 \\
(0.01 / 0.79)\end{array}$ & $\begin{array}{l}0.004 \\
(0.00 / 0.38)\end{array}$ & $\begin{array}{l}0.006 \\
(0.00 / 0.12)\end{array}$ & $\begin{array}{l}0.005 \\
(0.01 / 0.29)\end{array}$ \\
\hline Financial Loss & $\begin{array}{l}-0.001 \\
(0.01 / 0.86)\end{array}$ & $\begin{array}{l}-0.005 \\
(0.02 / 0.77)\end{array}$ & $\begin{array}{l}0.013 \\
(0.07 / 0.85)\end{array}$ & $\begin{array}{l}0.013 \\
(0.01 / 0.01)\end{array}$ & $\begin{array}{l}0.021 \\
(0.01 / 0.01)\end{array}$ & $\begin{array}{l}0.017 \\
(0.01 / 0.00)\end{array}$ & $\begin{array}{l}0.013 \\
(0.00 / 0.09)\end{array}$ & $\begin{array}{l}0.020 \\
(0.01 / 0.02)\end{array}$ & $\begin{array}{l}0.012 \\
(0.01 / 0.25)\end{array}$ \\
\hline Greenfield & $\begin{array}{l}0.007 \\
(0.03 / 0.95)\end{array}$ & $\begin{array}{l}0.040 \\
(0.02 / 0.02)\end{array}$ & $\begin{array}{l}-0.063 \\
(0.08 / 0.42)\end{array}$ & $\begin{array}{l}-0.022 \\
(0.01 / 0.03)\end{array}$ & $\begin{array}{l}-0.025 \\
(0.01 / 0.01)\end{array}$ & $\begin{array}{l}-0.027 \\
(0.01 / 0.02)\end{array}$ & $\begin{array}{l}-0.022 \\
(0.01 / 0.03)\end{array}$ & $\begin{array}{l}-0.023 \\
(0.01 / 0.02)\end{array}$ & $\begin{array}{l}-0.051 \\
(0.02 / 0.02)\end{array}$ \\
\hline Manufacturing & $\begin{array}{l}0.032 \\
(0.03 / 0.22)\end{array}$ & $\begin{array}{l}0.023 \\
(0.01 / 0.06)\end{array}$ & $\begin{array}{l}-0.017 \\
(0.04 / 0.67)\end{array}$ & $\begin{array}{l}0.004 \\
(0.00 / 0.45)\end{array}$ & $\begin{array}{l}0.001 \\
(0.00 / 0.69)\end{array}$ & $\begin{array}{l}-0.001 \\
(0.00 / 0.82)\end{array}$ & $\begin{array}{l}0.005 \\
(0.00 / 0.07)\end{array}$ & $\begin{array}{l}0.002 \\
(0.00 / 0.64)\end{array}$ & $\begin{array}{l}-0.000 \\
(0.01 / 0.73)\end{array}$ \\
\hline Wholesale & $\begin{array}{l}0.049 \\
(0.03 / 0.03)\end{array}$ & $\begin{array}{l}-0.058 \\
(0.02 / 0.00)\end{array}$ & $\begin{array}{l}-0.086 \\
(0.05 / 0.12)\end{array}$ & $\begin{array}{l}0.019 \\
(0.01 / 0.00)\end{array}$ & $\begin{array}{l}0.018 \\
(0.01 / 0.00)\end{array}$ & $\begin{array}{l}0.005 \\
(0.01 / 0.65)\end{array}$ & $\begin{array}{l}0.020 \\
(0.01 / 0.00)\end{array}$ & $\begin{array}{l}0.013 \\
(0.01 / 0.16)\end{array}$ & $\begin{array}{l}0.005 \\
(0.01 / 0.55)\end{array}$ \\
\hline Services & $\begin{array}{l}0.009 \\
(0.02 / 0.93)\end{array}$ & $\begin{array}{l}-0.033 \\
(0.01 / 0.00)\end{array}$ & $\begin{array}{l}-0.178 \\
(0.10 / 0.10)\end{array}$ & $\begin{array}{l}0.018 \\
(0.01 / 0.02)\end{array}$ & $\begin{array}{l}0.018 \\
(0.01 / 0.03)\end{array}$ & $\begin{array}{l}-0.005 \\
(0.01 / 0.43)\end{array}$ & $\begin{array}{l}0.018 \\
(0.01 / 0.02)\end{array}$ & $\begin{array}{l}0.010 \\
(0.01 / 0.14)\end{array}$ & $\begin{array}{l}0.007 \\
(0.01 / 0.32)\end{array}$ \\
\hline Parent Industry & $\begin{array}{l}-0.008 \\
(0.02 / 0.67)\end{array}$ & $\begin{array}{l}-0.030 \\
(0.01 / 0.00)\end{array}$ & $\begin{array}{l}-0.120 \\
(0.02 / 0.00)\end{array}$ & $\begin{array}{l}-0.008 \\
(0.00 / 0.00)\end{array}$ & $\begin{array}{l}-0.004 \\
(0.00 / 0.00)\end{array}$ & $\begin{array}{l}-0.004 \\
(0.00 / 0.13)\end{array}$ & $\begin{array}{l}-0.008 \\
(0.00 / 0.00)\end{array}$ & $\begin{array}{l}-0.002 \\
(0.00 / 0.00)\end{array}$ & $\begin{array}{l}-0.013 \\
(0.00 / 0.00)\end{array}$ \\
\hline Peer Exits & $\begin{array}{l}0.015 \\
(0.02 / 0.51)\end{array}$ & $\begin{array}{l}-0.005 \\
(0.01 / 0.43)\end{array}$ & $\begin{array}{l}-0.047 \\
(0.02 / 0.01)\end{array}$ & $\begin{array}{l}0.019 \\
(0.01 / 0.01)\end{array}$ & $\begin{array}{l}0.020 \\
(0.01 / 0.01)\end{array}$ & $\begin{array}{l}0.008 \\
(0.00 / 0.00)\end{array}$ & $\begin{array}{l}0.019 \\
(0.01 / 0.01)\end{array}$ & $\begin{array}{l}0.009 \\
(0.00 / 0.00)\end{array}$ & $\begin{array}{l}0.010 \\
(0.00 / 0.00)\end{array}$ \\
\hline Policy Stability & $\begin{array}{l}-0.083 \\
(0.07 / 0.00)\end{array}$ & $\begin{array}{l}0.005 \\
(0.01 / 0.69)\end{array}$ & $\begin{array}{l}-0.016 \\
(0.02 / 0.50)\end{array}$ & $\begin{array}{l}-0.006 \\
(0.00 / 0.00)\end{array}$ & $\begin{array}{l}-0.004 \\
(0.00 / 0.03)\end{array}$ & $\begin{array}{l}-0.004 \\
(0.00 / 0.01)\end{array}$ & $\begin{array}{l}-0.006 \\
(0.00 / 0.00)\end{array}$ & $\begin{array}{l}-0.003 \\
(0.00 / 0.06)\end{array}$ & $\begin{array}{l}0.000 \\
(0.00 / 0.92)\end{array}$ \\
\hline Market Attractiveness & $\begin{array}{l}0.049 \\
(0.04 / 0.06)\end{array}$ & $\begin{array}{l}0.006 \\
(0.01 / 0.48)\end{array}$ & $\begin{array}{l}0.010 \\
(0.03 / 0.77)\end{array}$ & $\begin{array}{l}-0.014 \\
(0.01 / 0.00)\end{array}$ & $\begin{array}{l}-0.010 \\
(0.00 / 0.00)\end{array}$ & $\begin{array}{l}-0.004 \\
(0.00 / 0.03)\end{array}$ & $\begin{array}{l}-0.013 \\
(0.01 / 0.02)\end{array}$ & $\begin{array}{l}-0.004 \\
(0.00 / 0.05)\end{array}$ & $\begin{array}{l}-0.028 \\
(0.01 / 0.00)\end{array}$ \\
\hline Exposure & & $\begin{array}{l}-0.002 \\
(0.02 / 0.92)\end{array}$ & $\begin{array}{l}-0.022 \\
(0.04 / 0.60)\end{array}$ & $\begin{array}{l}0.020 \\
(0.00 / 0.00)\end{array}$ & $\begin{array}{l}0.006 \\
(0.00 / 0.00)\end{array}$ & $\begin{array}{l}0.006 \\
(0.00 / 0.00)\end{array}$ & $\begin{array}{l}0.011 \\
(0.01 / 0.02)\end{array}$ & $\begin{array}{l}0.008 \\
(0.00 / 0.01)\end{array}$ & $\begin{array}{l}0.239 \\
(0.05 / 0.00)\end{array}$ \\
\hline At-Risk Resources & $\begin{array}{l}0.002 \\
(0.00 / 0.90)\end{array}$ & & $\begin{array}{l}-0.024 \\
(0.01 / 0.04)\end{array}$ & $\begin{array}{l}0.000 \\
(0.00 / 0.73)\end{array}$ & $\begin{array}{l}0.001 \\
(0.00 / 0.64)\end{array}$ & $\begin{array}{l}-0.001 \\
(0.00 / 0.02)\end{array}$ & $\begin{array}{l}-0.003 \\
(0.00 / 0.19)\end{array}$ & $\begin{array}{l}-0.002 \\
(0.00 / 0.03)\end{array}$ & $\begin{array}{l}-0.032 \\
(0.01 / 0.00)\end{array}$ \\
\hline Resilience & $\begin{array}{l}-0.007 \\
(0.02 / 0.80)\end{array}$ & $\begin{array}{l}-0.034 \\
(0.01 / 0.01)\end{array}$ & & $\begin{array}{l}0.019 \\
(0.00 / 0.00)\end{array}$ & $\begin{array}{l}0.025 \\
(0.00 / 0.00)\end{array}$ & $\begin{array}{l}0.019 \\
(0.01 / 0.01)\end{array}$ & $\begin{array}{l}0.022 \\
(0.00 / 0.00)\end{array}$ & $\begin{array}{l}0.028 \\
(0.00 / 0.00)\end{array}$ & $\begin{array}{l}-0.272 \\
(0.09 / 0.00)\end{array}$ \\
\hline
\end{tabular}




\section{Exposure $X A R R$}

Exposure X Resilience

0.015

$(0.01 / 0.02)$

$-0.015$

$(0.01 / 0.04)$
0.017

$-0.016$

$(0.01 / 0.02)$
0.049

$(0.01 / 0.00)$

0.145

Instrumental

Variables

War Zone Coverage 1.260

$\quad(0.03 / 0.00)$

Lagged ARR $\quad 0.798$

Lagged Resilience

$(0.02 / 0.00)$

Constant

$-0.163$

$(0.03 / 0.00)$

$\mathrm{N}$

6,480

pseudo $\mathrm{R}^{2}$

0.490

Shea's partial $\mathrm{R}^{2}$

First-stage $F$-statistic

Wald $\chi^{2}$

a Standardized coefficients are reported with robust standard errors clustered

0.671

$-0.198$

$(0.10 / 0.00)$

$(0.03 / 0.00) \quad(0.03 .0 .00)$

$6,453 \quad 4.544 \quad 6,480$

$\begin{array}{ll}4.544 & 6,480 \\ 0.480 & 0.030\end{array}$

6,453

4,544

6,335

6,452

2,678

0.394

0.673

638.378

0.032

0.024

0.032

0.020

0.028

Tests of Endogeneity for Treatment Effects (ML) Regressions:

Wald-test of independent equations for main effects model: $\operatorname{chi} 2(1)=0.84(p=0.3583)$

Wald-test of independent equations for full model: $\operatorname{chi} 2(1)=0.40(p=0.5255)$

Tests of Endogeneity, Relevance, and Validity of Instruments for GMM IV Regressions (ARR):

Wu-Hausman $F$-test for exogeneity of ARR variable: $F(1,6433)=1.63799(p=0.2006)$

Durbin-Wu-Hausman test for exogeneity of ARR variable: Durbin (score) chi2 $(1)=1.64241(p=0.2000)$

Anderson canonical correlations test of under-identification for instrument lagged ARR: Chi2 $(1)=3134.31(p=0.0000)$

Cragg-Donald Wald $F$ test of weak-identification $F$-statistic $=3039.39$; Stock-Yogo 10\% maximal IV size critical value: 7.03

Kleibergen-Paap test of under-identification: Chi2 $(1)=37.36(p=0.0000)$

Tests of Endogeneity, Relevance, and Validity of Instruments for GMM IV Regressions (Resilience):

Wu-Hausman $F$-test for exogeneity of resilience variable: $F(1,2659)=4.29808(p=0.0383)$

Durbin-Wu-Hausman test for exogeneity of resilience variable: Durbin (score) chi2 $(1)=4.32181(p=0.0376)$

Anderson canonical correlations test of under-identification for instrument lagged resilience: $\mathrm{Chi} 2(1)=26.08(p=0.0000)$

Cragg-Donald Wald $F$ test of weak-identification $F$-statistic=13.08; Stock-Yogo 10\% maximal IV size critical value: 7.03

Kleibergen-Paap test of under-identification: $\mathrm{Chi} 2(1)=37.28(p=0.0000)$ 
Figure 1. Relative Exit Rates of MNEs as a Function of Exposure and At-Risk Resources

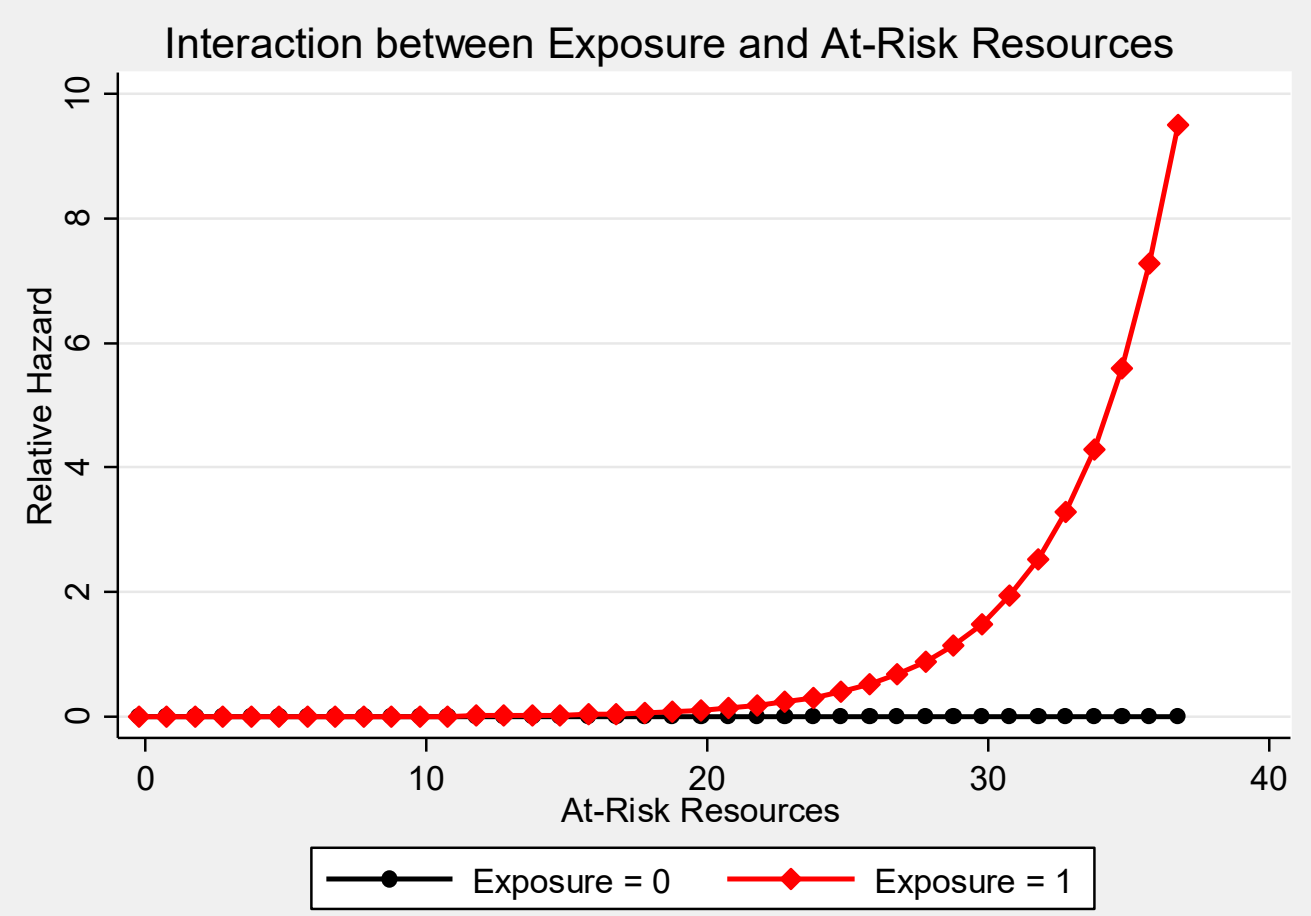

Figure 2. Relative Exit Rates of MNEs as a Function of Exposure and Resilience

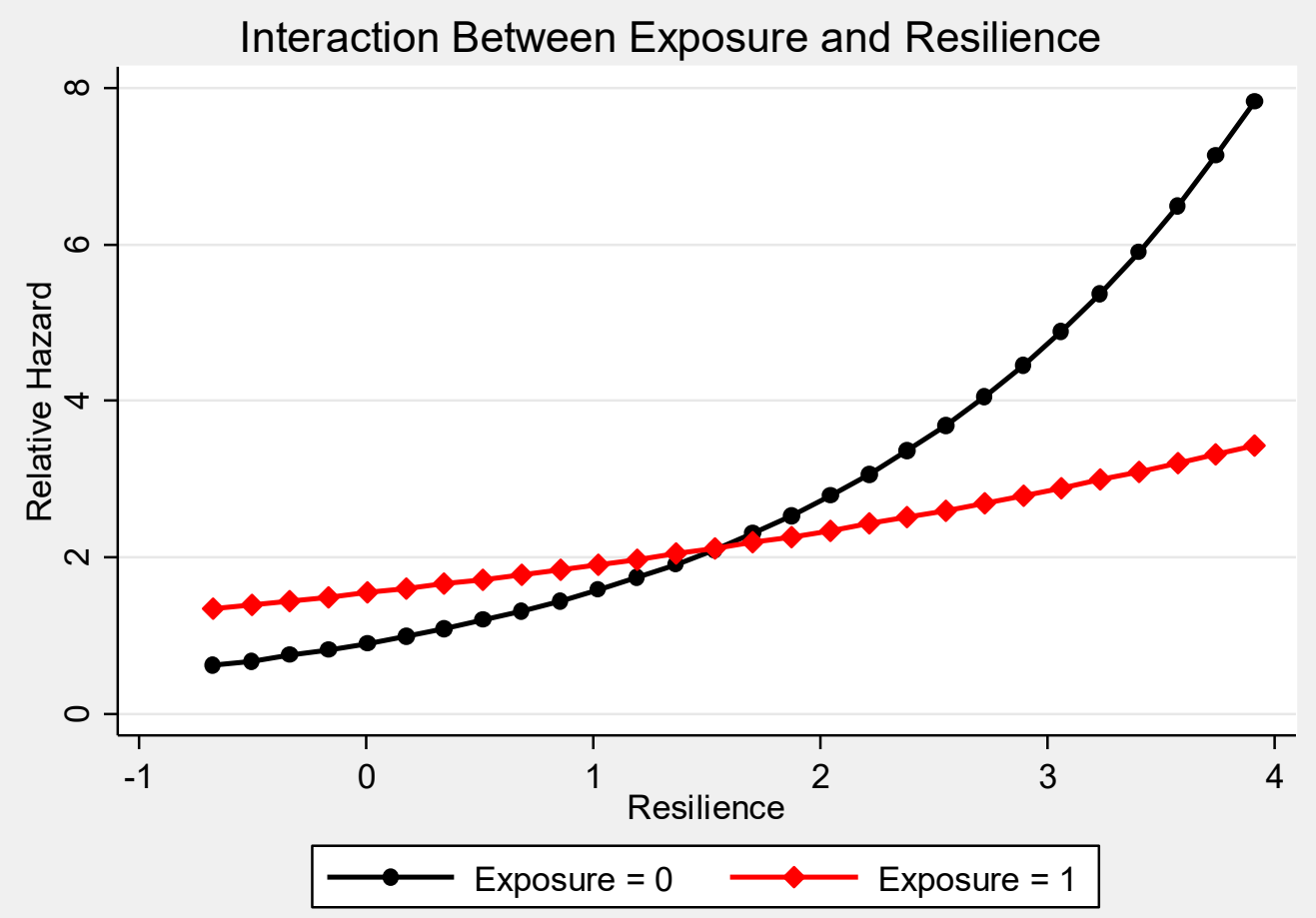

